\title{
Patrimônio geológico no estado de São Paulo
}

\author{
Geological heritage in the the state of São Paulo \\ VIRGINIO MANTESSO-NETO , ROGÉRIO RODRIGUES RIBEIRO , MARIA DA GLÓRIA MOTTA GARCIA, \\ ELIANE APARECIDA DEL LAMA , ANTONIO THEODOROVICZ . \\ ${ }^{1}$ Conselho de Monumentos Geológicos / SP - virginio@uol.com.br \\ ${ }^{2}$ Instituto Geológico de São Paulo - rrribeiro@igeologico.sp.gov.br \\ 3Instituto de Geociências da Universidade de São Paulo-mgmgarcia@gmail.com - edellama@usp.br \\ ${ }^{4} C P R M / S P$ - antonio.theodorovicz@cprm.gov.br
}

\begin{abstract}
Resumo
O Estado de São Paulo tem cerca de $250.000 \mathrm{~km}^{2}$ e 41 milhões de habitantes, com uma taxa de urbanização que ultrapassa $95 \%$. Sua geologia é constituída de cerca de $30 \%$ de embasamento cristalino, cerca de $70 \%$ de Bacia do Paraná e pequenas bacias terciárias e quaternárias; sua geomorfologia reflete essencialmente a base geológica. Seu patrimônio geológico natural é rico e variado, cobrindo quase toda a história terrestre, múltiplas litologias, e uma grande variedade de cavernas, incluindo um dos maiores portais calcários do mundo; o patrimônio geológico construído é também muito abrangente, incluindo o uso de rochas locais e importadas. A história da mineração no seu território abrange algumas das primeiras minas do Brasil e tem importância continental. O estado criou o primeiro Conselho de Monumentos Geológicos do país, tem geossítios de valor científico internacional e está desenvolvendo seu inventário. Tem potencial para pelo menos um geoparque. Conta com muitas instituições de ensino e pesquisa nas geociências, e diversos museus. Por tudo isso, a perspectiva para o bom uso do seu patrimônio geológico, com a preservação adequada, é uma possibilidade real e um dos objetivos de sua comunidade geocientífica.
\end{abstract}

Palabras clave: São Paulo; patrimônio geológico natural; patrimônio geológico construído; geoparque; geoturismo.

\begin{abstract}
The State of São Paulo has an area of $250.000 \mathrm{~km}^{2}$ (97.000sq. mi.) and a population of 41 million inhabitants, of which over $95 \%$ in urban areas. Its geology is made up of about $30 \%$ of crystalline basement terrains, about $30 \%$ of Paraná Basin terrains and minor tertiary and quaternary basins; its geomorphology clearly reflects its geological basis. Its natural geological heritage is rich and varied, covering most of the Earth's history, multiple lithologies, and a large variety of caves, including one of the largest limestone portals in the world. Its built geological heritage is also quite meaningful, including the use of both domestic and imported dimension stones. The history of mining in its territory includes some of the oldest mines in Brazil and has continent-wide meaning. This state created the first Council of Geologic Monuments in the country, has geosites of international significance, and is developing its inventory of geosites. It has the potential for at least one geopark. It has many geoscience researching and teaching institutions, which host a number of museums. For all of these reasons, the perspective for the proper use of its geological heritage, with adequate preservation, is a real one, and one of the goals of its geoscientific community.
\end{abstract}

Key words: Sao Paulo; natural geological heritage; built geological heritage; geopark; geotourism.

\section{INTRODUÇÃO}

O Estado de São Paulo tem $248.223 \mathrm{~km}^{2}$; está dividido em 14 regiões administrativas, com 645 municípios e 4 regiões metropolitanas; sua população em 2013 é de 42,3 milhões de habitantes, dos quais 20,1 milhões na Região Metropolitana da Capital. A taxa de urbanização é muito alta, e era, em 2010, acima de $95,9 \%$. (SEADE, 2013). Neste trabalho apresentamos uma visão geral e abrangente sobre o patrimônio geológico no estado, tentando cobrir as várias facetas do tema, e suas interfaces com outras áreas das geociências e mesmo outras ciências, inclusive humanas.

Dividimos o Patrimônio Geológico em dois grandes grupos: o natural e o construído. O patrimônio natural é constituído por geossítios, onde o aspecto de interesse apresenta-se essencialmente em seu estado original, e a intervenção humana, se houve, teve efeito mínimo. O patrimônio construído abrange todos os elementos da geodiversidade que, por intervenção humana, tornaram-se itens de valor patrimonial. No Brasil começou a ser recentemente constatado o resultado já conhecido em outros países de que roteiros geoturísticos são muito úteis na divulgação e disseminação do conhecimento geocientífico, além de contribuir para a preservação do patrimônio geológico. Assim, esperamos que esse artigo, sem ser um guia, possa eventualmente ser usado como tal, estimulando o usufruto e o estudo dessa rica herança geológica e cultural.

\section{ESBOÇOS DA GEOLOGIA E GEOMORFOLOGIA}

Em grandes linhas, quase $30 \%$ do território paulista correspondem ao Embasamento Cristalino (com 
idades entre Arqueano e Proterozoico Superior) e quase $70 \%$ à Bacia do Paraná (do Devoniano ao Cretáceo), ocorrendo ainda pequenas áreas com coberturas cenozoicas, incluindo bacias (intracontinentais e costeiras) terciárias e pacotes sedimentares litorâneos (também intracontinentais e costeiros) quaternários (Figura 1).

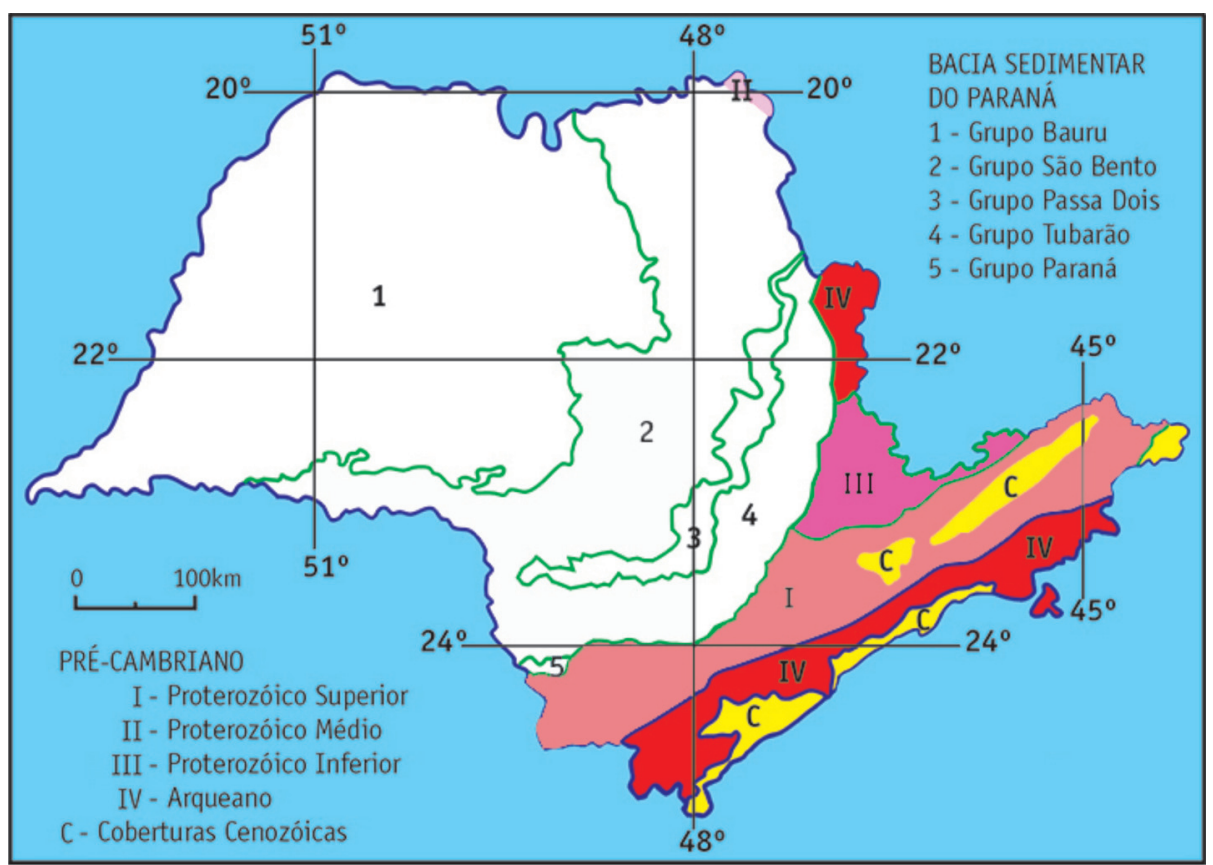

Figura 1-Esboço Geológico do Estado de São Paulo, segundo Santos (2004).

As características geomorfológicas são fortemente condicionadas pela estrutura geológica; são reconhecíveis, por critérios morfoesculturais, as seguintes grandes unidades geomorfológicas: Província Costeira, Planalto Atlântico, Depressão Periférica, Cuestas Basálticas e Planalto Ocidental (Figura 2).

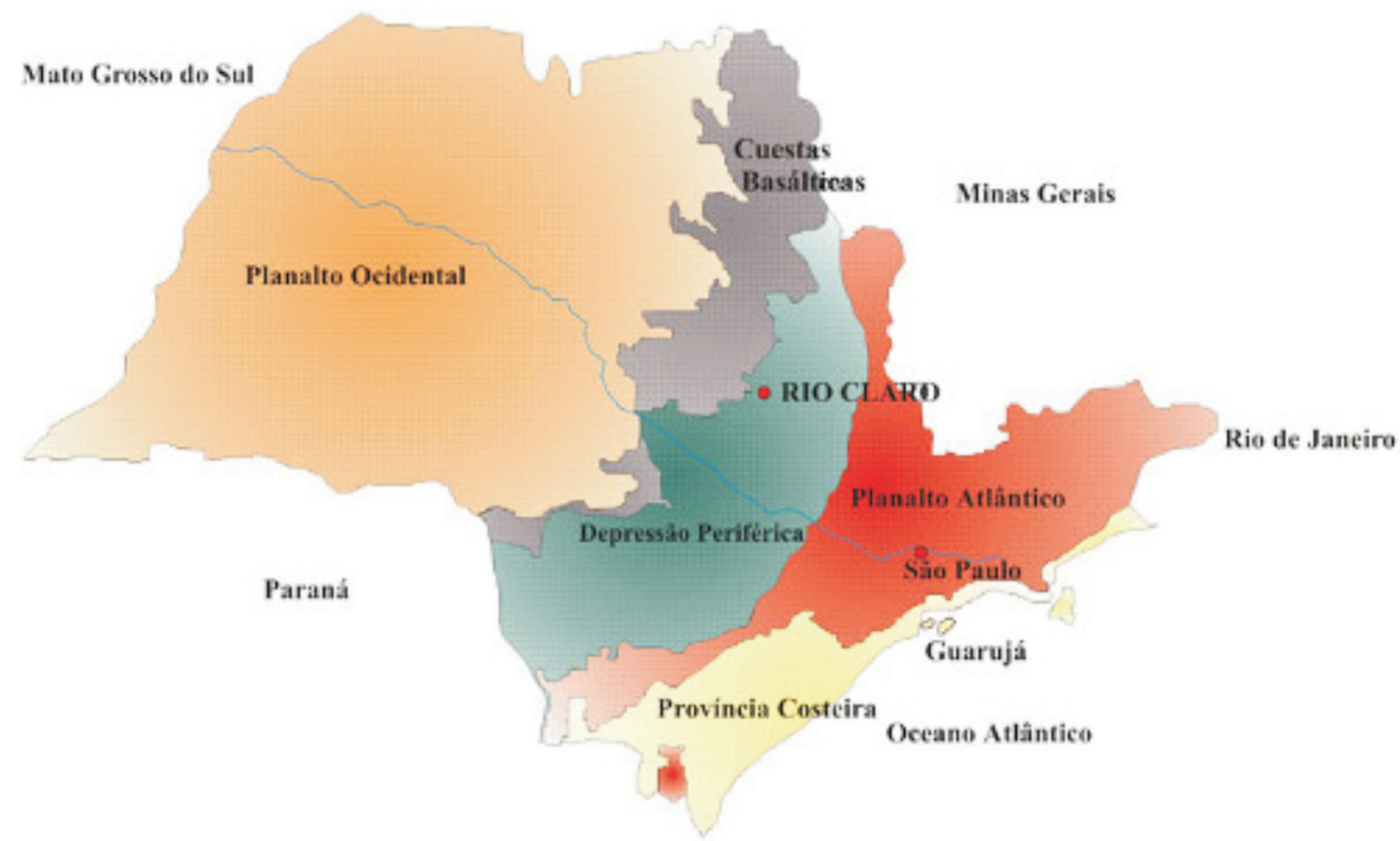

Figura 2 - Esboço Geomorfológico do Estado de São Paulo, baseado no conceito de morfoesculturas (Estado de Sao Paulo images, s/d). 
Como se nota no esboço geológico da Figura 1, as duas unidades principais do estado são a Bacia do Paraná, a noroeste, e o embasamento cristalino, a sudeste. Um roteiro que tenha início no extremo noroeste (p. ex. em Ilha Solteira) até o extremo sudeste (p. ex. em Santos) mostrará inicialmente rochas jurocretáceas do topo da Bacia do Paraná pertencentes aos grupos Ba urue São B ento, de a m biente predominantemente continental, seguidas de litotipos permo-triássicos do Grupo Passa Dois, de ambiente continental eólico e, em seguida, rochas de ambientes glácio-marinhos do Grupo Itararé (Carbonífero /Permiano). Localmente, a sudeste, ocorrem também depósitos fluviais a costeiros devonianos do Grupo Paraná, que constituem a base da sequência sedimentar que compõe a bacia no estado. O conjunto todo repousa sobre uma faixa alongada orientada na direção nordestesudoeste composta na sua maior parte por rochas metamórficas de baixo a alto grau cortadas por corpos granitoides de diferentes idades. Esseembasamento cristalino tem idades desde arqueanas ( $3 \mathrm{Ga}$ ) até proterozoicas superiores (chegando, pontualmente, a cambrianas, $500 \mathrm{Ma}$ ) e foi afetado por inúmeros eventos tectônicos. Numerosas falhas e zonas de cisalhamento transcorrentes geradas como resultado de colisões continentais registram os episódios de aglutinação do Supercontinente Gondwana, no Neoproterozoico, que corresponde ao último grande evento termo-tectônico que afetou a região - o Brasiliano/Pan-Africano. No Cretáceo teve início a fragmentação do Gondwana e a abertura do Oceano Atlântico Sul, durante a qual o desenho atual da linha de costa do Continente Sul-Americano começou a ser delineado. Subprodutos tardios destes movimentos extensionais, tais como as bacias cenozoicas (Taubaté, São Paulo, etc.) distribuídas ao longo de um rifte orientado paralelamente à costa e a Serra do Mar, uma das mais espetaculares feições do sul-sudeste do Brasil, também foram gerados, além de planícies litorâneas e bacias costeiras, como a de Santos.

Em razão desta grande diversidade de rochas, estruturas, paisagens e processos geológicos construídos ao longo de quase toda a história do planeta, o Estado de São Paulo, detém, em seu território, geossítios de valor inestimável, seja pela relevância geocientífica, beleza cênica ou importância histórica. Vários destes geossítios já se constituem em (ou estão bastante próximos de) locais de turismo convencional ou de turismo de aventura. Alguns já estão disponíveis como locais de visitação geoturística e possuem projetos de divulgação e proteção. A maioria deles, entretanto, carece de ações que promovam a interface entre o patrimônio natural e as comunidades, uma situação que representa um grande desafio para o poder público, a comunidade científica e a sociedade.

\section{HISTÓRICO DO RECONHECIMENTO E GESTÃO DO PATRIMÔNIO GEOLÓGICO}

As primeiras ações governamentais visando a gestão do patrimônio natural geológico no Estado de São Paulo tiveram início na década de 1970, com o tombamento parcial da de uma antiga pedreira de varvito no município de Itu, em 1974, pela Secretaria Estadual da Cultura.

Outras ações governamentais visando a gestão do patrimônio natural geológico iniciaram-se com a publicação do Decreto Estadual no 11.138/78. Este documento colocava sob a égide da antiga Divisão de Proteção de Recursos Naturais (DPRN) e do Instituto Geológico (IG), então órgãos da Secretaria de Estado da Agricultura (SAA), a elaboração de normas técnicas que visavam o uso racional, a salvaguarda e o serviço de conservação dos Monumentos Geológicos para fins científicos e culturais, bem como a perpetuidade de monumentos naturais por meio de regimes especiais de proteção (arts. 368, IX e X; 423, IX). Posteriormente, já na década de 1980, boa parte dessas atribuições foram reunidas e repassadas definitivamente ao Instituto Geológico, por meio da criação da Seção de Monumentos Geológicos, quando da expedição do Decreto Estadual no $24.931 / 86$ (art. $10^{\circ}$, III). No ano de 1987, o IG se desacoplou da Secretaria da Agricultura e foi transferido para a recém-criada Secretaria de Estado do Meio Ambiente (SMA) (Decreto № 26.942/87, arto 1ㅇ).

Na transição dessas duas décadas a gestão do patrimônio geológico ganhou outro aliado, a Secretaria de Estado da Cultura, por meio do Decreto Estadual $n^{\circ}$ 13.426/79. Neste documento, observa-se um estímulo à valorização cultural e à proteção desse patrimônio, ao ser preconizada a necessidade da defesa dos monumentos naturais paisagísticos por meio do tombamento (arts. $3^{\circ}$ e $140, \S 1^{\circ}$ ). Finalmente, em 1989 , a promulgação da atual Constituição Paulista ratificou a valorização do patrimônio geológico como bem natural a ser tombado, ao incluir como patrimônio cultural a ser protegido "os conjuntos urbanos e sítios de valor histórico, paisagístico, artístico, arqueológico, paleontológico, ecológico e científico" (art. 260).

Na década de 1990, duas importantes ações do poder público local foram a criação do Parque Municipal da Rocha Moutonneé, em 1991, em Salto, e do Parque Municipal Varvito de Itu, em 1995.

O Instituto Geológico, por meio da Seção de Monumentos Geológicos, teve forte atuação na gestão do patrimônio natural geológico paulista até meados da década de 1990, quando iniciou contatos com as prefeituras do estado solicitando indicações ou sugestões de ocorrência de lugares com interesse geológico em seu território, que merecessem um estudo técnico. Entretanto, por falta de pesquisadores e de pessoal técnico, esta Seção ficou praticamente inoperante até 2007, quando foi reativada com a 
inserção, via concurso público, de novos pesquisadores científicos e com o lançamento dos projetos "Monumentos Geológicos do Estado de São Paulo" e "Monumentos Geológicos da Região de Rio Claro".

Em 2009 foi criado, por meio da Resolução SMA no 076/2009, o Conselho Estadual de Monumentos Geológicos (CoMGeo-SP), junto à Secretaria de Estado de Meio Ambiente. O CoMGeo-SP, de caráter consultivo, tem como principal objetivo auxiliar, no âmbito da SMA, as ações e atividades que envolvam a pesquisa, conservação e divulgação dos Geossítios e Monumentos Geológicos de São Paulo. É composto pelo Secretário do Meio Ambiente (seu presidente), pelo diretor do IG, pelo chefe da Seção de Monumentos Geológicos (seu Secretário Executivo) e por outros 16 Conselheiros, vindos de diversas áreas de atuação e conhecimento, e reconhecidos por sua atuação nos temas relacionados aos Geossítios e Monumentos Geológicos.

No âmbito acadêmico, duas iniciativas pioneiras podem ser citadas dentro do Instituto de Geociências da Universidade de São Paulo: 1) A criação, em 2011, do Núcleo de Apoio à Pesquisa em Patrimônio Geológico e Geot ur ismo d a Uni versi dad e de S ão Paul o (GeoHereditas), com o apoio da Pró-Reitoria de Pesquisa da USP. O núcleo tem como objetivos principais promover a pesquisa, a geoconservação e a divulgação do patrimônio geológico no Estado de São Paulo e em outros estados, tendo como alicerces a Geologia Básica, a divulgação das Geociências e a melhoria da qualidade de vida das comunidades envolvidas. 2) Uma nova linha de pesquisa, denominada "Patrimônio Geológico natural e construído e Geoconservação", foi incluída, em 2012, no Programa de Pós-Graduação em Mineralogia e Petrologia do IGc/USP.

\section{INICIATIVAS NAÁREA DE PATRIMÔNIO GEOLÓGICO}

No estado, há várias instituições com programas ligados a aspectos do movimento pela valorização do patrimônio geológico. Os principais programas e iniciativas são:

\subsection{MONUMENTOS GEOLÓGICOS DO ESTADO DE SÃO PAULO}

O já mencionado Projeto "Monumentos Geológicos do Estado de São Paulo" tem como principal objetivo promover o registro, conhecimento, conservação e divulgação do Patrimônio Geológico estadual, abordando a geodiversidade como arcabouço fundamental da biodiversidade. Visa também preencher uma lacuna na gestão do patrimônio natural geológico, permitindo que o Estado de São Paulo coloque-se em posição compatível com as ações já existentes em esfera mundial e em outros estados do Brasil.

Alguns produtos deste Projeto são a sua logomarca, o Inventário Paulista (Preliminar) dos
Monumentos Geológicos, os primeiros marcadores de página da série "Monumentos Geológicos de São Paulo" e painéis geológicos (Figuras 3 a 6), além da ficha de proposta de criação de Monumento Geológico, folders e bloco de notas.

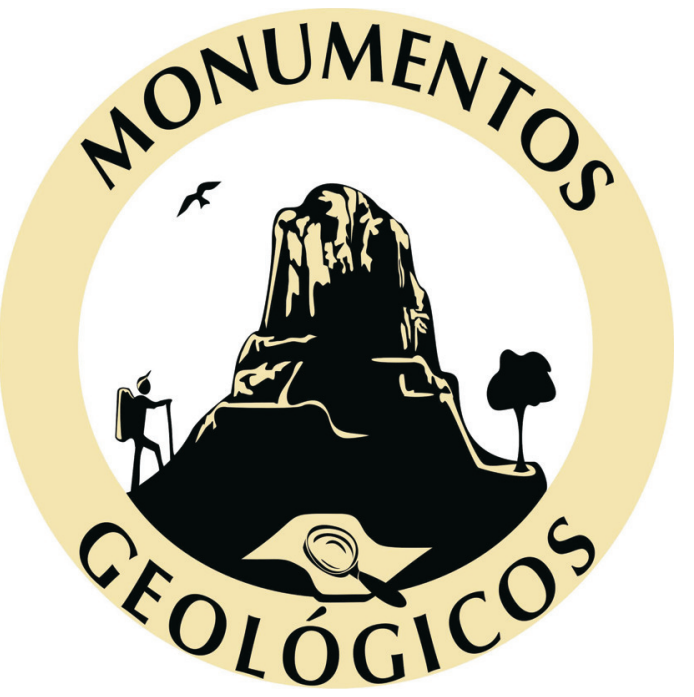

Figura 3 - Imagem ilustrativa da Logo do Projeto Monumentos Geológicos de São Paulo.

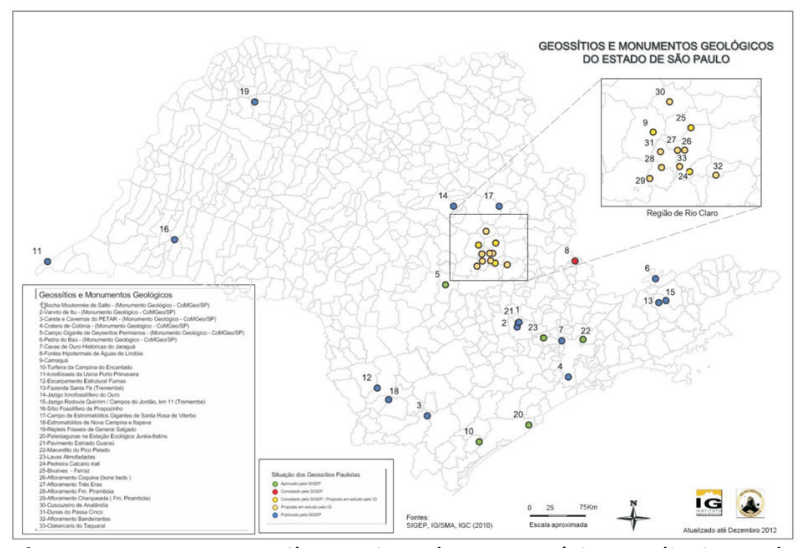

Figura 4 - Imagem ilustrativa do Inventário Preliminar de Geossítios e Monumentos Geológicos Paulistas do Projeto Monumentos Geológicos de São Paulo.
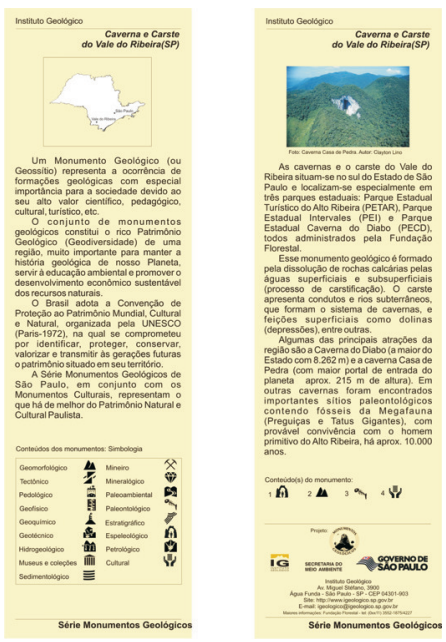

Figura 5 - Imagem ilustrativa do marcador de página (frente e verso) do Projeto Monumentos Geológicos de São Paulo. 


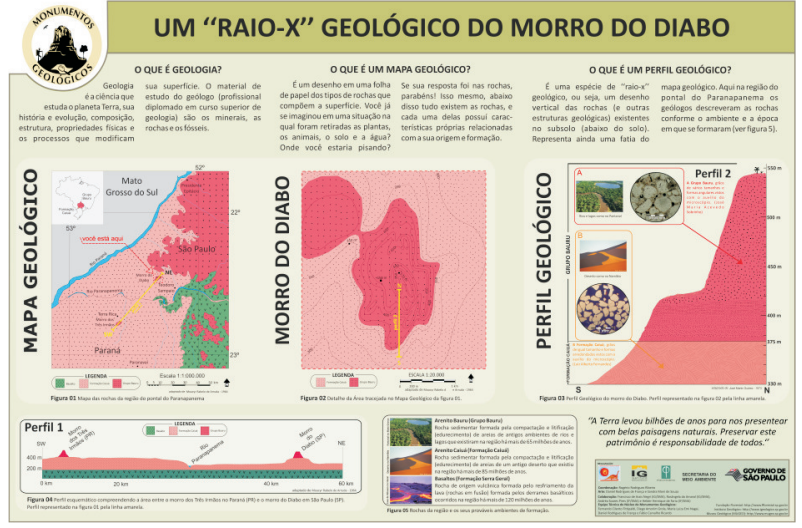

Figura 6 - Imagem ilustrativa do Painel Geológico do Projeto Monumentos Geológicos de São Paulo.

Dos cerca de trinta geossítios identificados no território paulista (pela SIGEP - ver item 4.6 - e por instituições de pesquisa), até meados de 2013, seis apresentaram as condições mínimas para uma gestão adequada e foram declarados como Monumentos Geológicos Paulistas pelo CoMGeo-SP. São eles: O Carste e as Cavernas do Parque Estadual Turístico Alto do Ribeira (PETAR); a Rocha Moutonnée; o Varvito de Itu; a Cratera de Colônia; os Geyseritos de Anhembi; e a Pedra do Baú. Os demais sítios deverão ser paulatinamente apreciados pelo mesmo fórum.

\subsection{MONUMENTOS GEOLÓGICOS DA REGIÃO DE RIO CLARO}

De 2007 até 2012 foi desenvolvido o Projeto "Monumentos Geológicos da Região de Rio Claro" (Figuras 7 e 8). Essa região é composta pelos municípios de Analândia, Charqueada, Corumbataí, Ipeúna, Itirapina, São Pedro, Rio Claro, Limeira e Santa Gertrudes. É conhecida por apresentar um patrimônio natural bastante diverso, e já conta com trabalhos de levantamento do patrimônio geológico elaborados por Zaine \& Perinotto (1996), Perinotto (2009), Zaine \& Zaine (2009) e Perinotto \& Mantesso-Neto (2013a, 2013b), com importantes considerações sobre o potencial turístico da área e propostas de educação ambiental.

Foram objetivos deste projeto:

a) contribuir para o registro, o conhecimento e a divulgação do Patrimônio Geológico do Estado de São Paulo;

b) identificar, selecionar e caracterizar o patrimônio geológico de excepcional valor científico existente na região, como forma de suportar iniciativas de geoconservação;

c) contribuir com o Inventário Paulista dos Monumentos Geológicos (Ribeiro et al., 2012).
Foram identificados onze locais com ocorrência de elementos da geodiversidade apresentando significativo valor científico. Segundo a metodologia utilizada para inventário e quantificação desses onze geossítios, quatro apresentaram também valor científico em nível internacional. A próxima fase será o encaminhamento desses geossítios para apreciação por parte do Conselho de Monumentos Geológicos (CoMGeo-SP).

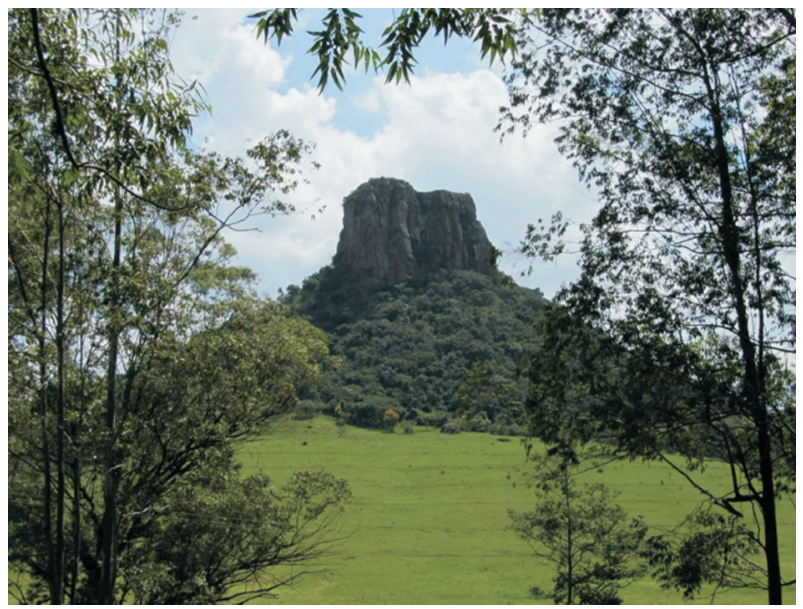

Figura 7 - Elemento da área coberta pelo Projeto Monumentos Geológicos da Região de Rio Claro: o Cuscuzeiro de Analândia, morro-testemunho constituído por arenitos da Formação Botucatu (Bacia do Paraná, idade jurássica), localmente "cozidos" e silicificados pelo basalto da Formação Serra Geral (Foto: Virginio Mantesso-Neto).

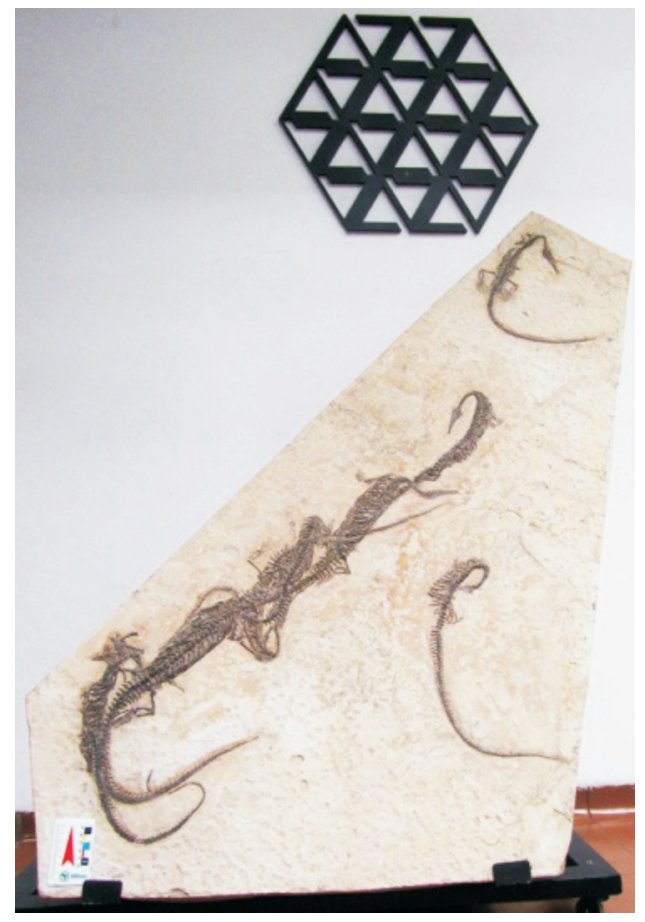

Figura 8 - Elemento da área coberta pelo Projeto Monumentos Geológicos da Região de Rio Claro: Formação Irati (Bacia do Paraná, idade permiana), da qual se origina esta placa de calcário, notável por apresentar 9 fósseis de mesossaurídeos, todos com o crânio preservado, e indícios de que um deles seja de uma fêmea prenha. Museu de Geociências IGc/USP. Escala $5 \mathrm{~cm}$. (Foto: Virginio Mantesso- Neto). 


\subsection{VALE DO RIBEIRA - PARQUES E GEOPARQUE}

Consequência de uma longa e complexa história geológica que, do Arqueano ao Fanerozoico, envolveu a superposição de vários eventos tectônicos de abertura e fechamento de mares e oceanos, e consequentes colisões de massas continentais e intensa granitogênese associada, a região sul-paulista, limítrofe com o estado do Paraná, conhecida como Vale do Ribeira, se caracteriza por ser uma das mais complexas e variadas na geologia do Brasil. É um geoambiente especial em vários sentidos. Notadamente na sua porção mais montanhosa, conhecida como Alto Vale do Ribeira, apresenta um rico e diversificado patrimônio geológico, ambiental, paisagístico e mineral, com destaque para uma das maiores concentrações das mais belas e impressionantes cavernas do mundo (cerca de 300 conhecidas), muitas das quai s com fei çõ es úni ca $s$ e em pleno desenvolvimento (Figuras 9 a 12). O estado de São Paulo criou, pelo Decreto no 32.283 de 19/05/1958, o Parque Estadual e Turístico do Alto Ribeira - PETAR (www.petaronline.com.br), com a finalidade de resguardar e proteger o patrimônio espeleológico e a rica biodiversidade aí presentes; a SIGEP (ver item 4.6) reconheceu a região como um dos importantes patrimônios espeleológicos do Brasil, registrando esse $\mathrm{s}$ i s t e m a d e c a verna s c o m o sít i o 043 (sigep.cprm.gov.br/sitio043/sitio043.htm).

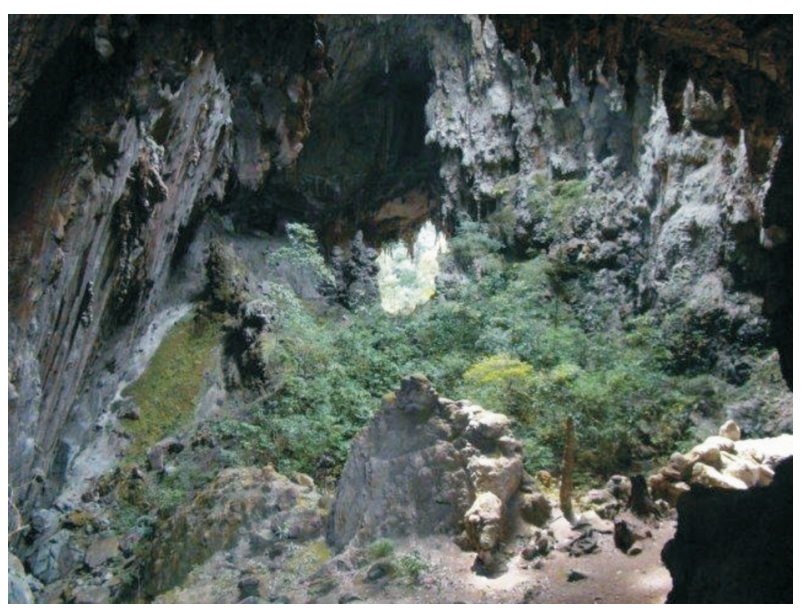

Figura 9 - Caverna Teminina, salão conhecido como Jardim Suspenso. Foto: Antonio Theodorovicz.

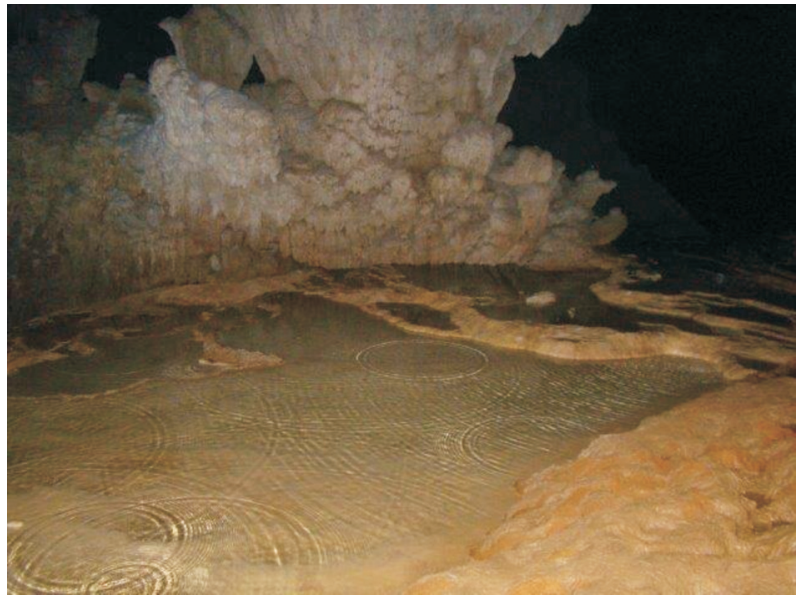

Figura 10 - Caverna Teminina, travertinos em formação. Foto: Antonio Theodorovicz.

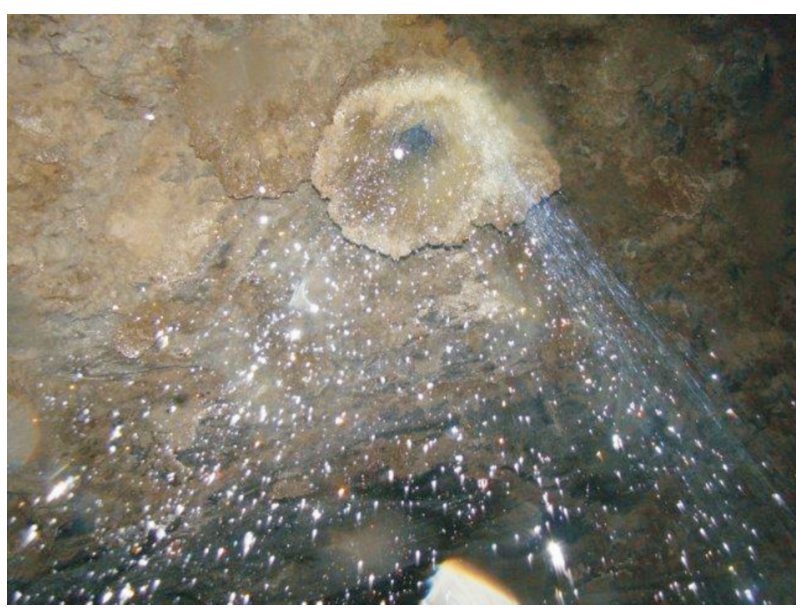

Figura 11 - Caverna Teminina, jato d'água saindo do teto da caverna como uma grande ducha. Foto: Antonio Theodorovicz.

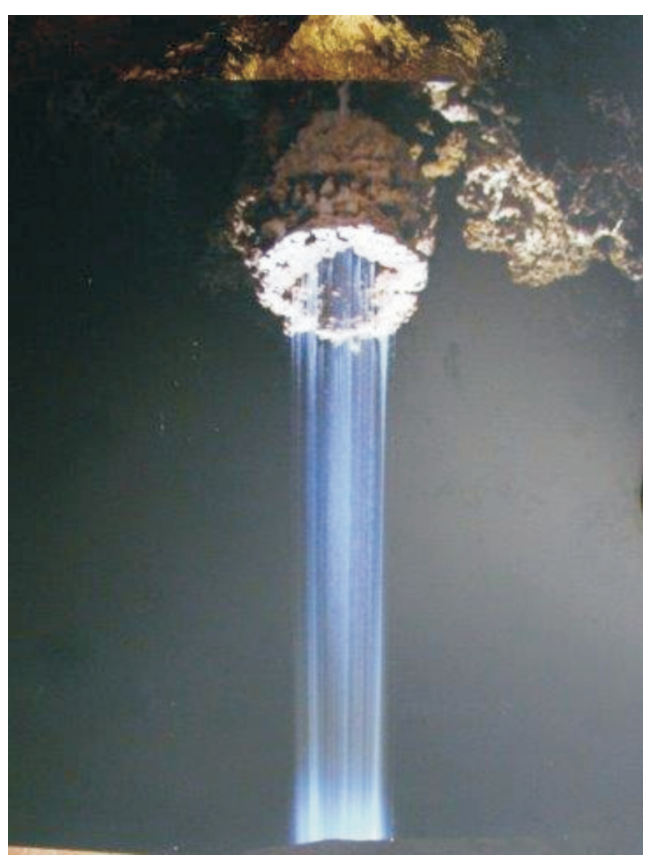

Figura 12 - Caverna Teminina, jato d'água saindo do teto da caverna como uma grande ducha. Tomada do painel existente no Núcleo Caboclos. Foto: Antonio Theodorovicz. 
Protegem e também aproveitam turisticamente o extraordinário patrimônio geológico e ambiental da região outras grandes áreas de preservação ambiental da categoria Parques do Sistema Nacional de Unidades de Conservação - SNUC, os parques estaduais Intervales PEl e Caverna do Diabo, e o Parque Municipal Morro do Ouro de Apiaí (www.apiai.sp.gov.br), este último criado com o intuito de proteger e aproveitar uma antiga mineração de ouro primário.

A lé $\mathrm{m}$ d o ext r a ordinário patrimônio espeleológico concentrado nas áreas dos parques, existem outros patrimônios naturais importantes, distribuídos por uma região bem mais abrangente do que a de domínio das áreas de conservação. Esses atributos, em seu conjunto, tornam essa região de alto potencial geoturístico também um didático laboratório a céu aberto para o estudo dos mais diversos temas da bio e geodiversidade. Parte desse patrimônio não está sendo preservado, sofrendo degradação pelo avanço desordenado das pastagens e dos reflorestamentos com espécies exóticas, que pouco a pouco homogeneízam a vegetação com todos seus impactos ambientais e cênicos negativos.

Infelizmente, causa também impacto negativo a constatação de que, contrastando com seu ricopatrimônio natural, a região é historicamenteconhecidapor ser uma das mais pobresdo estado, estando aí localizados alguns de seus municípios de menores IDHs. Essa contradição leva a concluir que não se está sabendo aproveitar adequadamente o que a região tem de melhor - seu patrimônio natural - como fator de melhoria das condições socioeconômicas da população. Muito se tem falado em mudar essa realidade através do ecoturismo. Projetos governamentais com esse intuito são muitos e antigos. No entanto, as iniciativas até o momento tomadas são tímidas e se concentram basicamente no incentivo à visitação às áreas dos parques.

Preocupa mais ainda o equivocado conceito que tem boa parte da população que não se beneficia economicamente do turismo praticado nos parques de que eles são um dos limitadores do desenvolvimento socioeconômico da região. Esse conceito leva essa população a rechaçar qualquer proposta de criação de novas unidades de preservação ambiental da categoria parques do SNUC. Essa postura, por sua vez, aumenta ainda mais o risco de degradação desse patrimônio.

É com essa preocupação que o Serviço Geológico do Brasil (SGB/CPRM), através do seu Projeto Geoparques(www.cprm.gov.br/publique/cgi/cgilua.ex / sys/start.htm?sid=134) achou por bem selecionar, dentre outras do Brasil, uma área de cerca de $2.500 \mathrm{~km}^{2}$ no Alto Vale do Ribeira (www.cprm.gov.br/Geo_Site/), que envolve partes de municípios paulistas de Apiaí, Iporanga, Ribeira, Barra do Turvo, Eldorado Paulista e Itaoca e do vizinho município paranaense de Adrianópolis, como adequada para aplicar uma novidade de uso e ocupação do solo que são os Geoparques termo criado pela UNESCO, para distinguir áreas do mundo onde o patrimônio geológico é preservado e, através do geoturismo, é aproveitado como indutor de crescimento econômico, de cultura e de educação ambiental.

É, portanto, um conceito de preservação totalmente distinto dos parques do SNUC, uma vez que um Geoparque não é cercado; não é necessário que seja uma figura jurídica; não envolve desapropriações; não exige a saída dos moradores; não proíbe nenhuma forma de uso e ocupação, nem mesmo da mineração (que pode até ser aproveitada como um atrativo turístico). É uma concepção de desenvolvimento sustentável que tem por objetivo melhorar as condições de vida da população e fazer com que ela passe a preservar e a ter orgulho do meio em que vive. Um Geoparque tem também por finalidade permitir que o turista ao visitá-lo se divirta, que possa, ao mesmo tempo, adquirir conhecimentos sobre a sua história e a sua importância geológica. Esse conhecimento é repassado principalmente por meio de painéis interpretativos montados em locais estrategicamente selecionados, denominados de Geossítios.

Geossítio é o termo empregado para caracterizar um local onde existe uma singularidade qualquer da geodiversidade que mereça ser preservada e visitada, seja pela sua exclusividade, ou pela sua importância para o entendimento da evolução geológica em nível local, regional ou global, ou seja, ainda, por qualquer outro aspecto ligado às ciências da Terra inclusive aspectos culturais ou históricos. A cada geossítio está normalmente associado um painel explicativo, que tem não apenas o objetivo de passar informações, mas também o de fazer o turista refletir sobre a geologia e o meio ambiente, e conscientizar-se da necessidade da preservação do seu entorno.

Muitas vezes, particularmente em regiões onde a paisagem - ou, em última análise, a geomorfologia - é um atrativo, o geossítio, além de suas outras características, é também um local de onde se pode admirar uma bela vista (Figuras 13 e 14). 


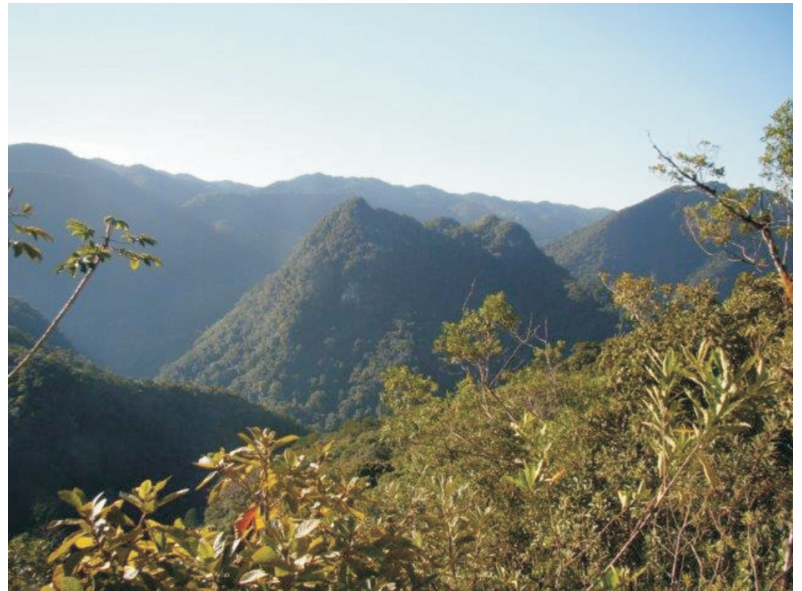

Figura 13 - Imagem tirada do mirante sobre o vale do rio Betari, exemplo de geossítio de interesse geológico, geomorfológico e turístico. O vale foi condicionado por duas histórias geológicas distintas, distantes no tempo geológico: a tectônica colisional Brasiliana, responsável pela deformação das sequências marinhas do Grupo Lajeado, e, no Fanerozoico, a abertura do Atlântico. A paisagem resultante - ou seja, a geomorfologia hoje visível - é um forte atrativo cênico. (Ver também Figura 14, tirada do mesmo local). Foto: Antonio Theodorovicz.

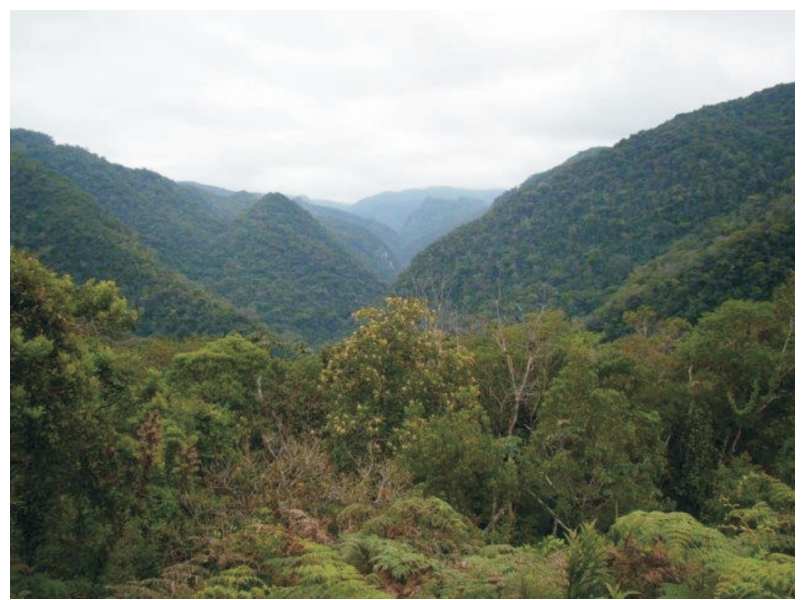

Figura 14-Imagem tirada do mirante sobre o vale do rio Betari, exemplo de geossítio de interesse geológico, geomorfológico e turístico. $\mathrm{O}$ vale foi condicionado por duas histórias geológicas distintas, distantes no tempo geológico: a tectônica colisional Brasiliana, responsável pela deformação das sequências marinhas do Grupo Lajeado, e, no Fanerozoico, a abertura do Atlântico. A paisagem resultante - ou seja, a geomorfologia hoje visível - é um forte atrativo cênico. (Ver também Figura 13, tirada do mesmo local). Foto: Antonio Theodorovicz.

Essa filosofia de uso do solo sob o formato de Geoparque coaduna-se perfeitamente com a realidade socioeconômica e ambiental da região, e também vem ao encontro dos projetos governamentais idealizados para o Vale do Ribeira, que têm como metas promover o seu desenvolvimento, enfatizado no ecoturismo. A aplicação desse conceito na região pode também ser uma ferramenta disciplinadora de práticas negativas de uso e ocupação e de convencimento da população de que é muito mais vantajoso economicamente aproveitar o patrimônio natural com o turismo do que depredá-lo com formas inadequadas de uso do solo.
Se uma entidade está situada numa região que apresenta características geológicas e outros atributos adequados, dispõe de infraestrutura receptiva e administrativa já em operação compatível com a filosofia de um Geoparque, e apresenta um dossier de candidatura, ela pode vir a receber da UNESCO um selo de aval e passar a integrar a Rede Global de Geoparques (Global Geoparks Network - www.globalgeopark.org). Essa rede busca manter, por um sistema de orientação, partilha e colaboração entre seus membros, uma plataforma de ações com o intuito de proteger e aproveitar o patrimônio geológico como indutor de educação, entretenimento e desenvolvimento sustentável.

Justificativas para tornar realidade um projeto de Geoparque na região, segundo os pressupostos da UNESCO, existem muitas. Dentre elas, salientam-se:

i) o excepcional patrimônio espeleológico e geológico (Figuras 13 a 22), em grande parte bem protegido nas áreas dos parques, porém também existentes em outros domínios, que necessitam ser preservados e podem ser mais bem aproveitados turisticamente que hoje são - o que seria importante para melhor socializar as benesses econômicas advindas do turismo, reconhecidamente gerador de muitos empregos;

ii) a excelente infraestrutura receptiva e educacional oferecida pelos parques, e à qual, para ficar adequada à filosofia turística de um Geoparque, falta apenas a sinalização geológica;

iii) a existência de afloramentos de rochas representativas de boa parte da história geológica das regiões Sul e Sudeste do Brasil, em especial do Proterozoico e do Fanerozoico. O Proterozoico é constituído, principalmente, pelas sequências metavulcanossedimentares e metassedimentares marinhas do Supergrupo Açungui (Figura 17), que, na região, agrega, por justaposição tectônica colisional Brasiliana, unidades geológicas das mais diferentes origens e idades. O Fanerozoico é espacialmente pouco extenso, porém, não menos importante, uma vez que é representado por diques de diabásio, relacionados à tectônica de abertura do Oceano Atlântico Sul, fato que desperta bastante curiosidade do turista;

iv) os vestígios da histórica atividade de mineração, que deixou um interessante legado arqueológico (Figura 18), arquitetônico e cultural, incluindo quilômetros de galerias subterrâneas (Figura 19), onde chumbo, prata e ouro foram, por muito tempo, explorados; essas galerias já são parcialmente aproveitadas em empreendimentos turísticos (Figura 20) e continuam sendo importantes para estudos geológicos e metalogenéticos; 
v) por toda a região o relevo é montanhoso, arquitetado com belas e curiosas formas e drenado por um denso e complexo sistema de cristalinos cursos d'água, muitos dos quais escorrendo sobre substrato rochoso formando corredeiras, cachoeiras e piscinas naturais (Figuras 21 e 22), constituindo um atrativo para o turismo contemplativo e para a prática de esportes radicais;

vi) a ocorrência de áreas contínuas e bem preservadas do pouco que resta neste estado da Mata Atlântica e ecossistemas associados (Figuras 23 e 24), de extraordinário valor turístico, botânico e ambiental, considerada pela UNESCO como Reserva da Biosfera variável que ganha cada vez mais proeminência no cenário turístico mundial atual e soma muitos pontos positivos na proposição de um Geoparque;

vii) - os aspectos culturais da típica tradição cabocla e das várias comunidades quilombolas; incluindo a produção da cerâmica artesanal com motivos zoomórficos e antropozoomórficos, única no Brasil;

viii) - o patrimônio arquitetônico da época do Brasil colônia, pequeno, porém bastante representativo.

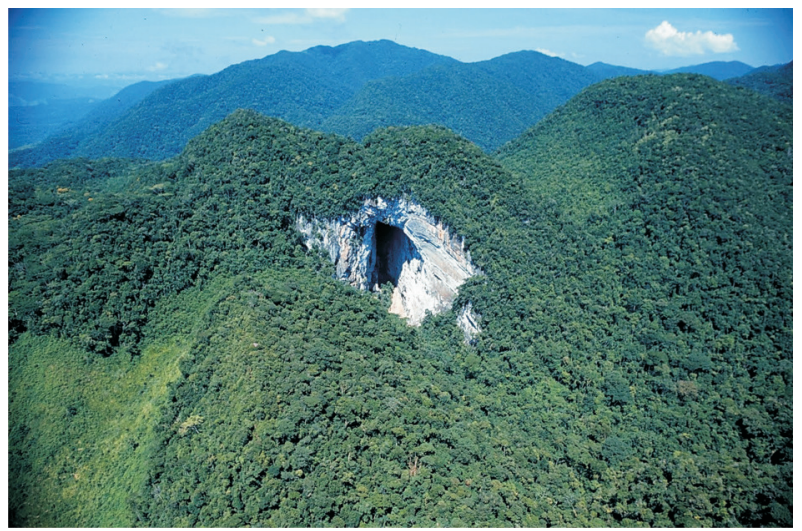

Figura 15 - Portal da caverna Casa de Pedra. Esculpido em um paredão calcário dobrado, com $219 \mathrm{~m}$ de altura, é um dos maiores portais do mundo. Foto: Antonio Theodorovicz.

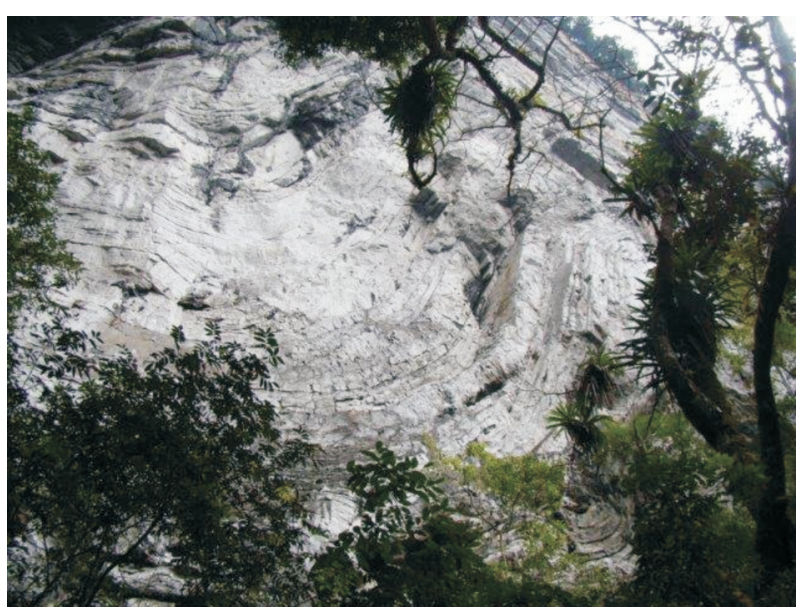

Figura 16-Exemplo de um local onde o turista pode observar os efeitos da deformação colisional Brasiliana sobre rocha calcária do Grupo Lajeado - um geossítio de interesse geológico, paleoambiental e turístico. Exposições desse tipo são raras no Brasil. Foto: Antonio Theodorovicz.

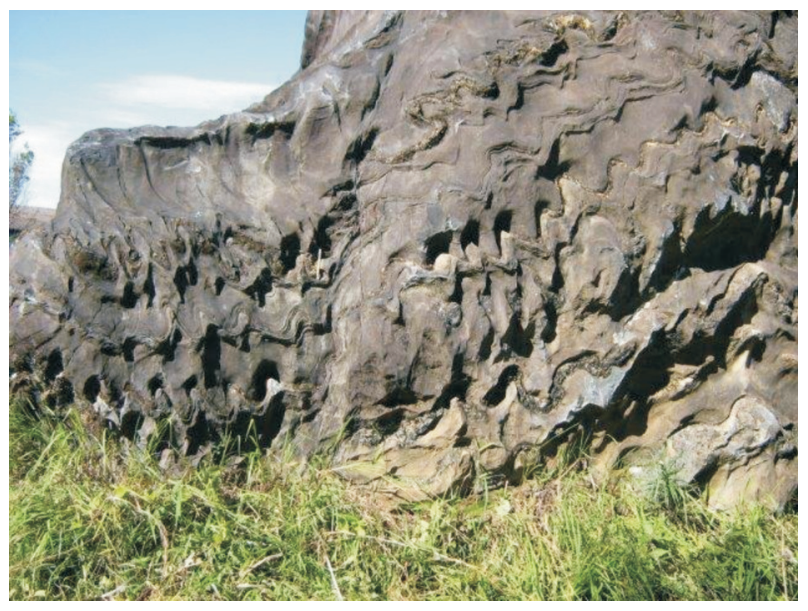

Figura 17 - Bloco de metamorfito dolomítico cinza do Grupo Açungui, comumente chamado "mármore de Apiaí", no qual a erosão diferencial formou figuras curiosas e surpreendentes. Foto: Antonio Theodorovicz.

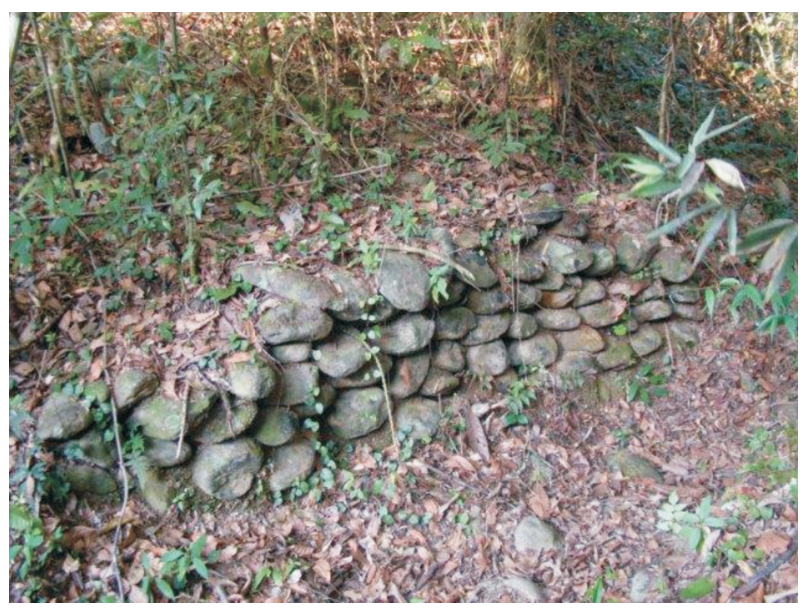

Figura 18 - Estrutura em pedra deixada pelas primeiras atividades garimpeiras de ouro aluvionar no Brasil, vestígio da ocupação da região desde meados do século XVI. Foto: Antonio Theodorovicz. 


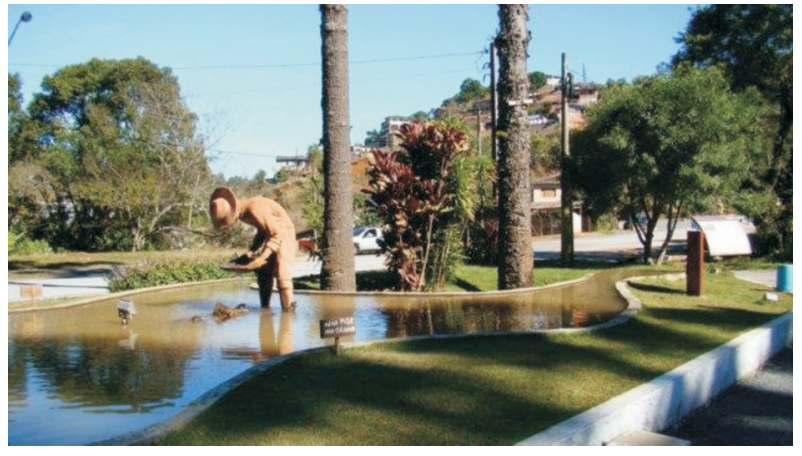

Figura 19 - O Parque Morro do Ouro, em Apiaí, é um bom exemplo de aproveitamento turístico relacionado à história da mineração. Entrada do Parque, com estátua de garimpeiro. Foto: Antonio Theodorovicz.

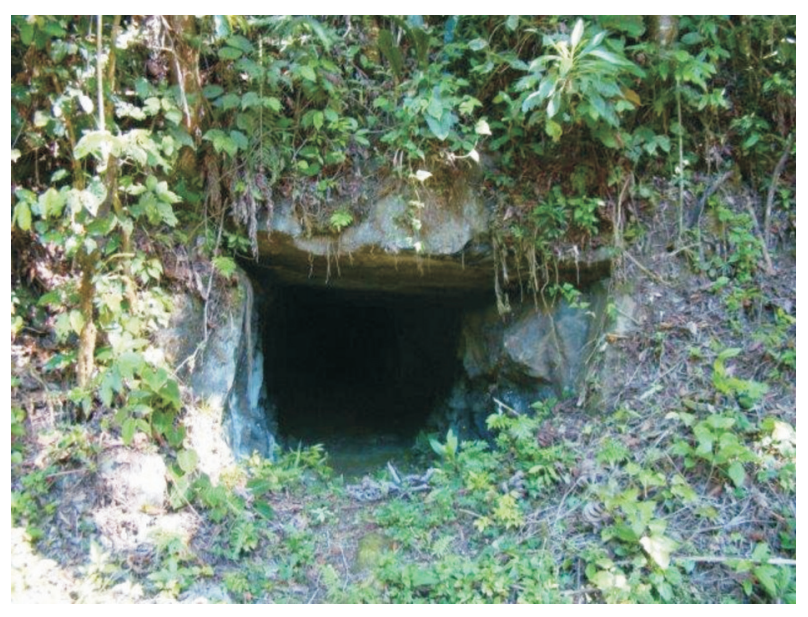

Figura 20 - O Parque Morro do Ouro, em Apiaí, é um bom exemplo de aproveitamento turístico relacionado à história da mineração. Uma das várias bocas de galeria da época da mineração de chumbo na Mina do Lageado, em Iporanga. Foto: Antonio Theodorovicz.

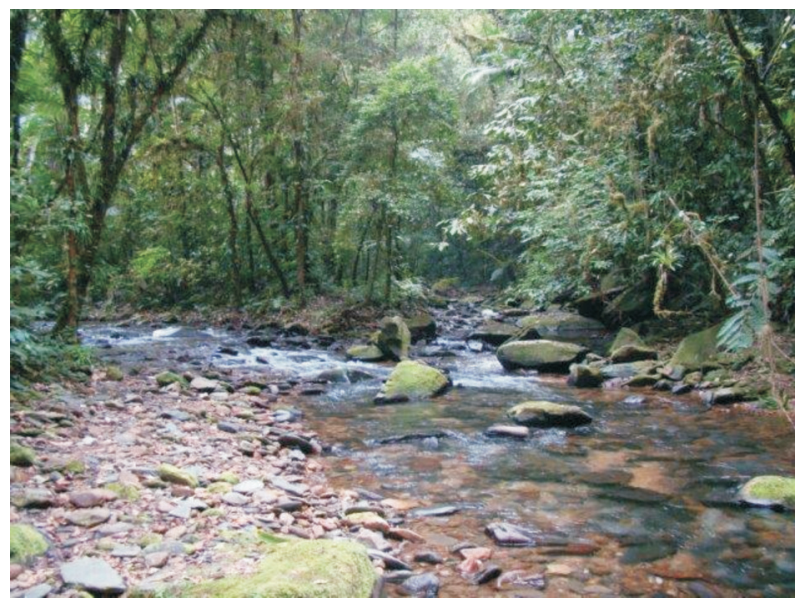

Figura 21 - Riachos de águas limpas e cachoeiras convidam o turista para uma caminhada. Rio Betari. Foto: Antonio Theodorovicz.

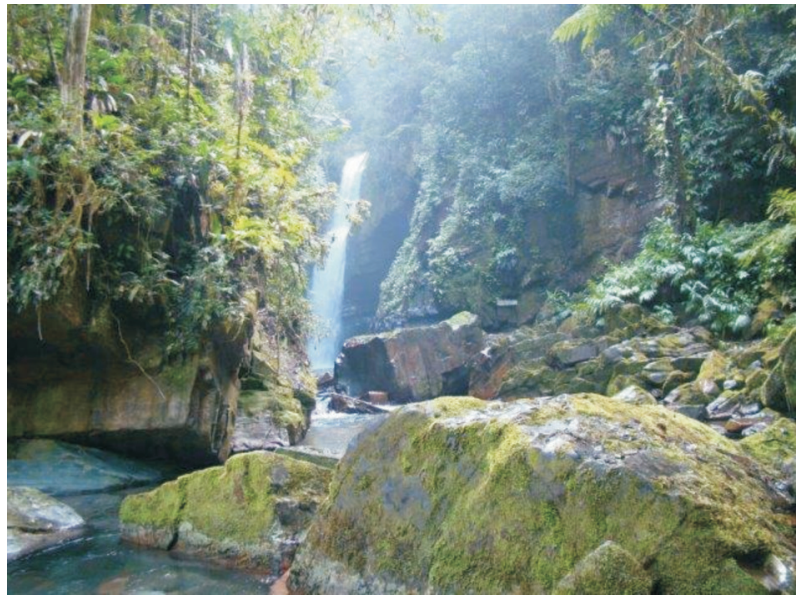

Figura 22 - Riachos de águas limpas e cachoeiras convidam o turista para uma caminhada. Cachoeira das Andorinhas. Foto: Antonio Theodorovicz.

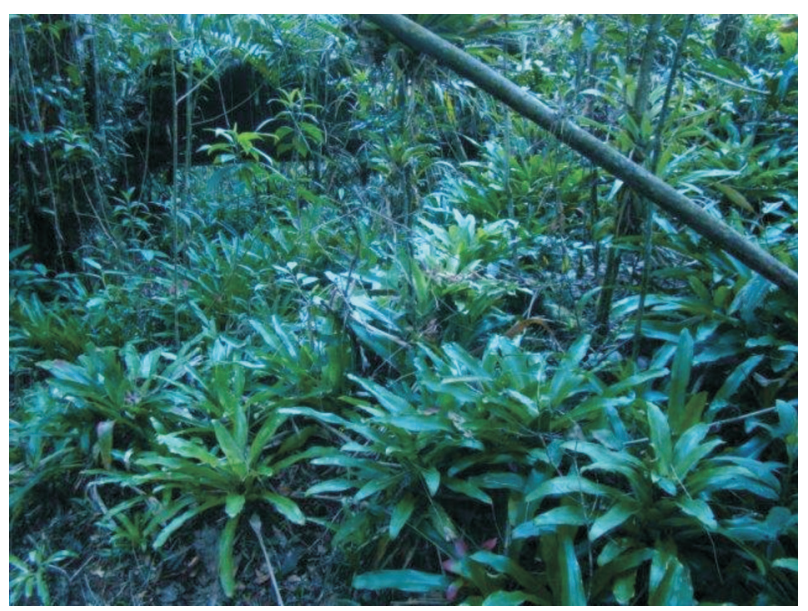

Figura 23 - Exemplo da exuberante vegetação da região, classificada pela UNESCO como Reserva da Biosfera. Foto: Antonio Theodorovicz.

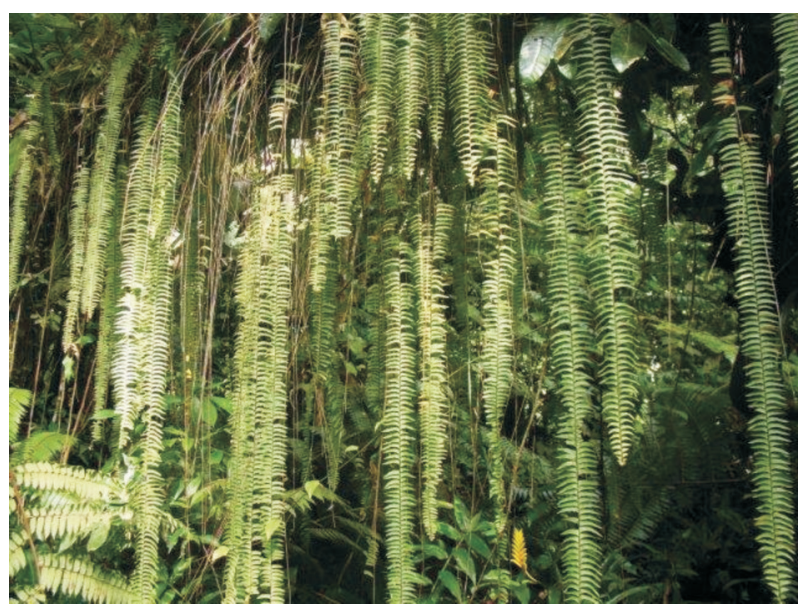

Figura 24 - Exemplo da exuberante vegetação da região, classificada pela UNESCO como Reserva da Biosfera. Foto: Antonio Theodorovicz. 
Pelo descrito, analisado à luz do conceito de geoparque e comparado com geoparques existentes em várias regiões do mundo, constata-se que a região tem condições para ser transformada em um Geoparque. Se esse conceito for bem aplicado, será uma maneira eficiente de preservar e melhor aproveitar economicamente esse extraordinário patrimônio natural. A decisão de transformar a proposta em realidade depende exclusivamente da vontade da população e de ações conjuntas entre os poderes municipal, estadual e federal. Ao SGB/CPRM, através de seu Projeto Geoparques, cabem os papeis de divulgador e indutor do processo, e de apoiador técnico, notadamente no que se refere às questões relacionadas ao tema geodiversidade.

\subsection{PATRIMÔNIO GEOLÓGICO DO LITORAL PAULISTA}

Este projeto está vinculado ao GeoHereditas, do IGc/USP e teve início em 2010 com um trabalho voltado à avaliação da potencialidade de trilhas nas Unidades de Conservação do Litoral Norte como geossítios. Como base inicial do trabalho, foram utilizadas as trilhas cadastradas no Passaporte de Trilhas de São Paulo, publicado pela Secretaria do Meio Ambiente do Estado. A escolha da região levou em consideração não apenas sua grande beleza natural, mas principalmente sua história geológica, que inclui registros da fusão, do desenvolvimento e da fragmentação do supercontinente Gondwana ao longo do Neoproterozoico-Paleógeno (Garcia et al., 2011; Garcia, 2012). Além disso, a região detém o maior segmento contínuo preservado da Mata Atlântica no Brasil, a maioria dos quais incluídos no Parque Estadual da Serra do Mar (PESM), que faz parte do Projeto de Preservação da Mata Atlântica (PPMA), o que aumenta sua importância como zona protegida. Embora essas unidades tenham sido criadas principalmente para preservar a biodiversidade, a região tem um grande potencial de geoturismo, pelos afloramentos rochosos e paisagens em diferentes estágios de evolução geológica. Grande parte dos atrativos turísticos presentes na região está relacionada a formações rochosas, a processos de sedimentação costeiros ou à dinâmica da paisagem, mas pouco é divulgado sobre a origem, idade ou processos que levaram à sua formação, bem como sobre as ameaças a que estão sujeitas.

A estes aspectos físicos somam-se registros de uma história de ocupação humana que remonta a 2.500 anos, além de inúmeras construções do período colonial que contam uma história de desafios entre os povos nativos e os conquistadores. O conjunto destes aspectos deu origem a uma cultura rica, caracterizada pela mistura de costumes de populações tradicionais diversas e que delinearam os valores culturais atuais. Neste sentido, o apoio à integração da população costeira e/ou geração de emprego e renda por estas atividades estão entre os principais focos do projeto, pois fazer o conhecimento científico não ficar limitado a instituições acadêmicas, bem como proporcionar melhores condições de vida para as comunidades locais, são as principais bases do Geoturismo.

Em meados de 2013, três dissertações de Mestrado (respectivamente nas regiões de Ubatuba, São Sebastião e Ilhabela) e uma tese de Doutorado (na região de Caraguatatuba) estão em andamento. Estas pesquisas têm como enfoque principal o inventário dos geossítios de acordo com critérios de relevância e potencial científicos e educacionais, mas locais onde a geodiversidade já constitui um atrativo turístico tradicional não foram descartados. Cerca de trinta geossítios, organizados em função da história geológica da região, foram definidos até o momento. Alguns deles são mostrados nas Figuras 25 a 28.

Na Praia de Camburizinho, a sul de São Sebastião, um belíssimo afloramento de gnaisses ortoderivados registra diferentes estágios dos eventos relacionados à amalgamação e separação do Gondwana desde o Neoproterozoico até o Mesozoico - dobras que evoluem para uma foliação regional transposta, paleodiques organizados como boudins de anfibolito com deformação interna e diques basáticos. Na Ilha Anchieta, em Ubatuba, um monzogranito datado em 500 Ma (Azevedo Sobrinho et al., 2011), representa um dos registros mais setentrionais do último evento orogênico antes da abertura do Atlântico Sul. O costão rochoso da Ponta da Sela, no sul de Ilhabela, registra exemplos de diques de composições, tamanhos e relações de intrusão variadas que, no conjunto, constituem uma feição onipresente no sudeste brasileiro e representam os estágios de fragmentação do Gondwana. Finalmente, a história geológica pós-fragmentação do Gondwana pode ser observada do Morro do Santo Antônio, em Caraguatatuba, de onde é possível ver a linha de costa, a planície sedimentar homônima, parte de São Sebastião e Ilhabela. Ao fundo, com seu relevo em blocos, destaca-se a feição morfológica mais relevante do litoral da região sudeste: a Serra do Mar.

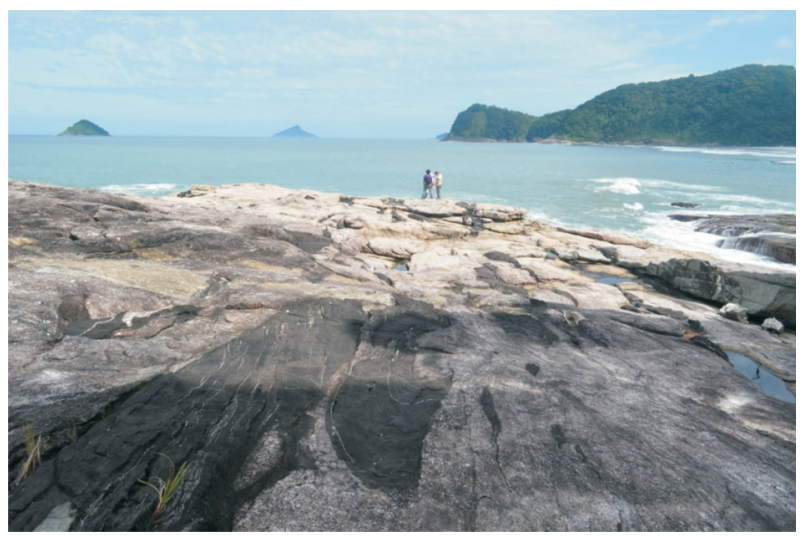

Figura 25 - Geossítio selecionado do Litoral Norte Paulista. Gnaisse ortoderivado com boudins anfibolíticos no llhote de Camburizinho, São Sebastião. Foto: Maria da Glória Motta Garcia. 


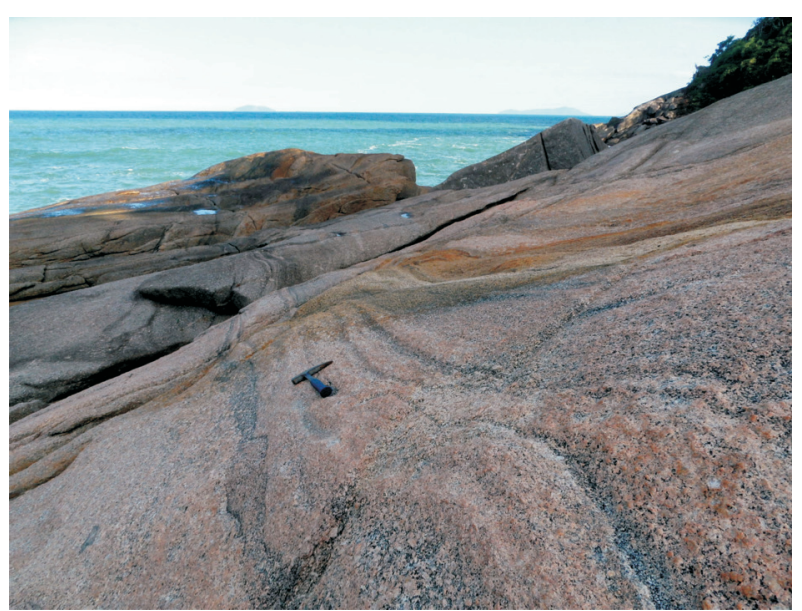

Figura 26 - Geossítio selecionado do Litoral Norte Paulista. Monzogranito Ilha Anchieta (500 Ma), Ubatuba. Foto: Maria da Glória Motta Garcia.

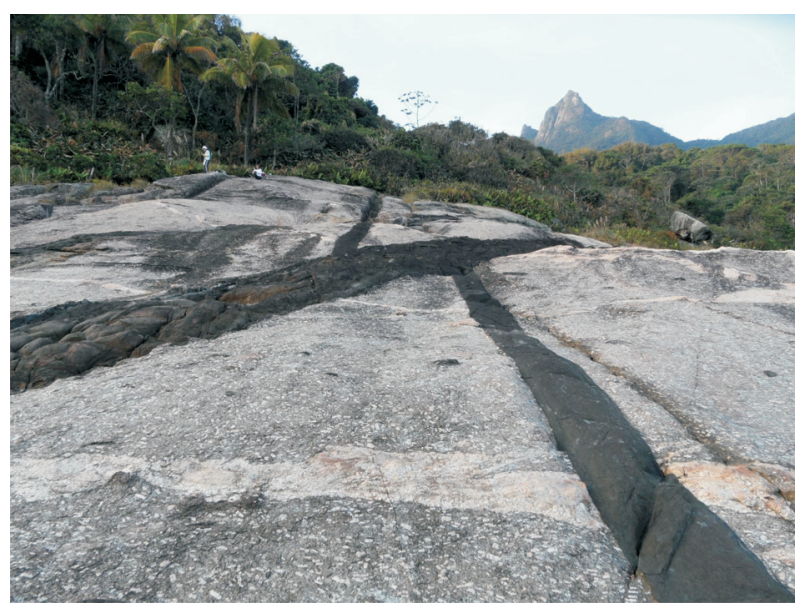

Figura 27 - Geossítio selecionado do Litoral Norte Paulista. Diques máficos e lamprófiros intrusivos em rochas do embasamento, Ilhabela. Foto: Maria da Glória Motta Garcia.

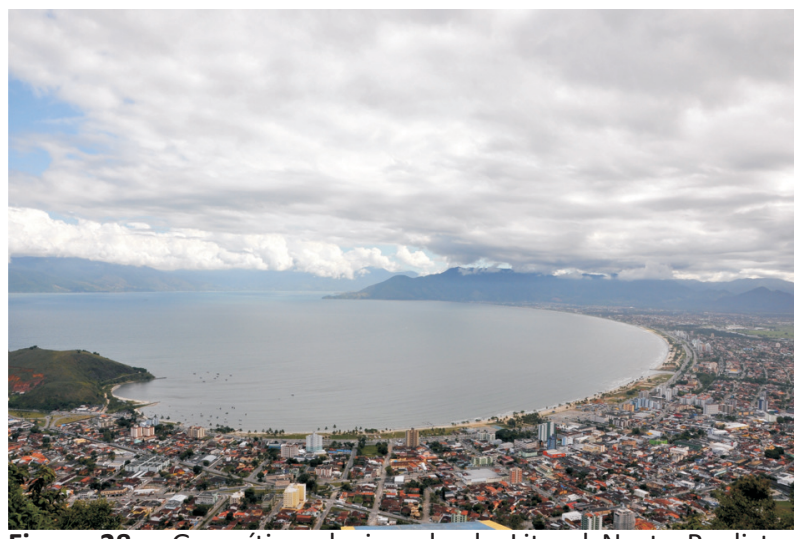

Figura 28 - Geossítio selecionado do Litoral Norte Paulista. Panorama visto do mirante do Morro de Santo Antonio, mostrando a planície costeira, a linha de costa e a Serra do Mar. Caraguatatuba. Foto: Eliane Aparecida Del Lama.

O inventário do patrimônio geológico do litoral central e sul do estado também está em andamento.

A gestão destes geossítios está em fase preliminar e inclui a confecção de um amplo plano geoturístico que envolva também os aspectos históricos e culturais e sirva de base para o desenvolvimento de um turismo sustentável na região. Além disso, a história geológica da região, além de conhecimento geológico básico, tem sido disseminada aos monitores ambientais das unidades de conservação envolvidas por meio de um projeto de Interpretação Geológica em Trilhas (Figuras 29 a 31). Experiências anteriores sugerem que o conhecimento da importância dos monumentos naturais e das paisagens é um passo imprescindível para que a população passe a valorizá-los e protegê-los. Ao tornarem-se agentes de disseminação do conhecimento, os monitores aprendem a valorizar não só a flora e a fauna, mas também a história da paisagem que os cerca, desenvolvendo o seu senso de pertencimento e de valorização do meio ambiente.

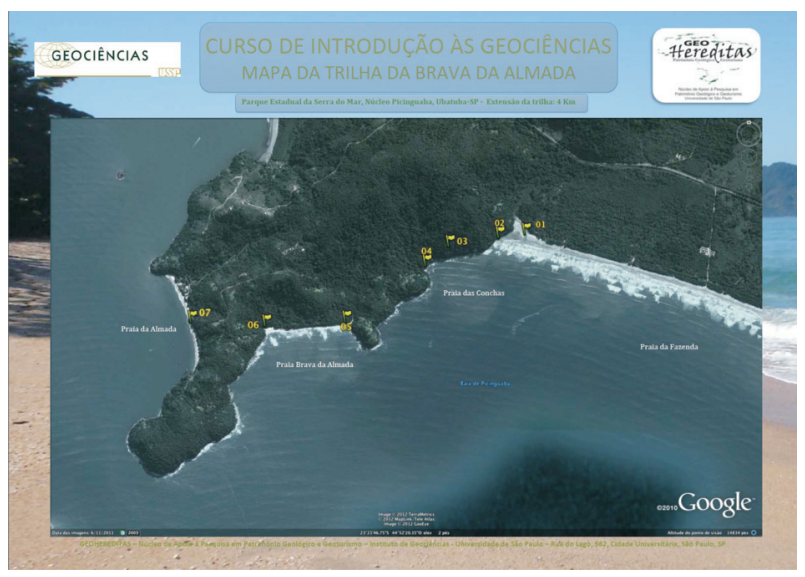

Figura 29-Exemplo de roteiro geodidático confeccionado com base em técnicas de interpretação ambiental e utilizado em curso ministrado a monitores ambientais no Núcleo Picinguaba do Parque Estadual da Serra do Mar, em Ubatuba. Mapa da Trilha da Brava da Almada, uma das mais percorridas do parque. Fotos: Maria da Glória Motta Garcia.

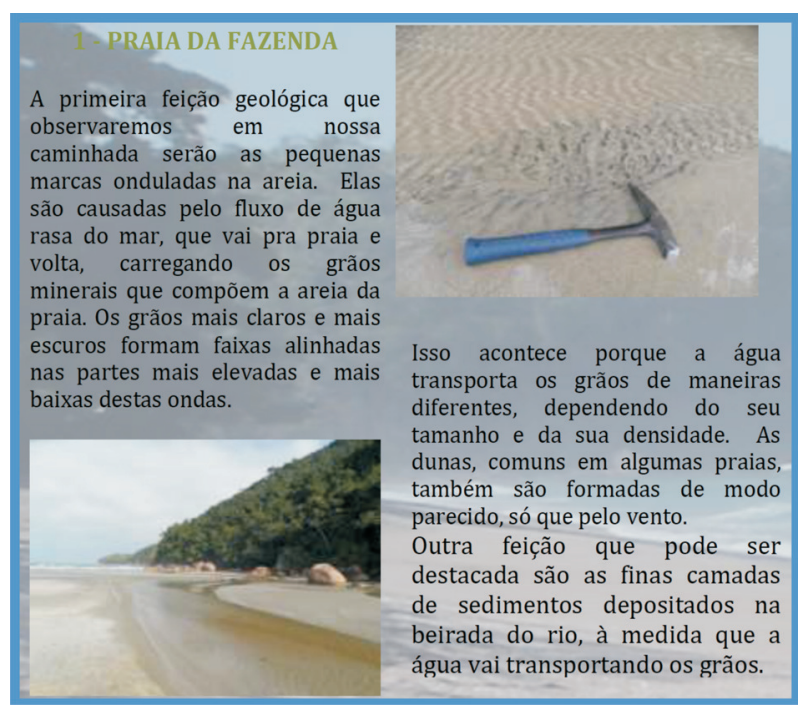

Figura 30 - Exemplo de roteiro geodidático confeccionado com base em técnicas de interpretação ambiental e utilizado em curso ministrado a monitores ambientais no Núcleo Picinguaba do Parque Estadual da Serra do Mar, em Ubatuba. Um de seus pontos de interpretação geológica. Fotos: Maria da Glória Motta Garcia. 


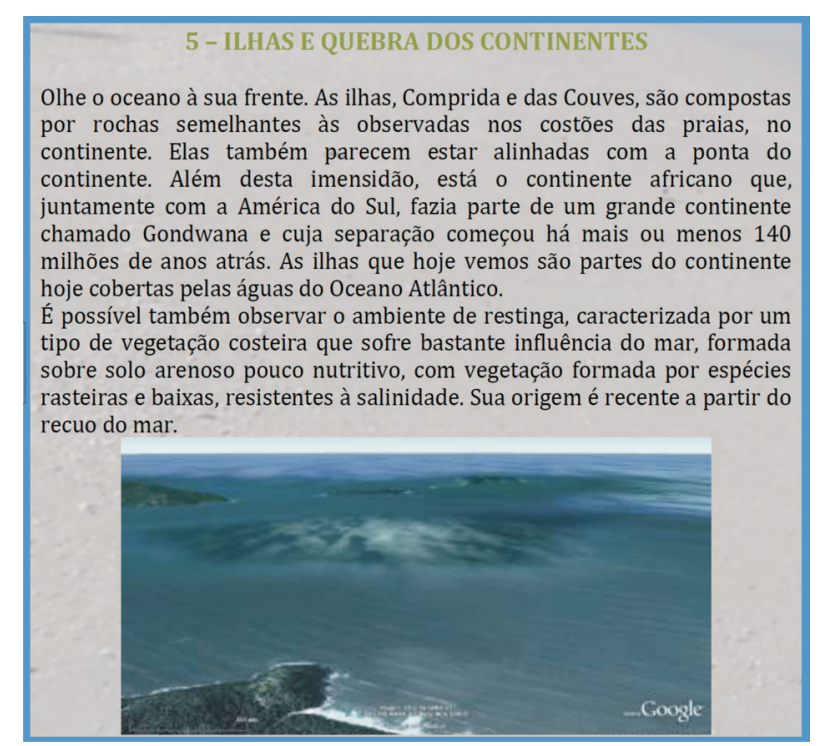

Figura 31 - Exemplo de roteiro geodidático confeccionado com base em técnicas de interpretação ambiental e utilizado em curso ministrado a monitores ambientais no Núcleo Picinguaba do Parque Estadual da Serra do Mar, em Ubatuba. Um de seus pontos de interpretação geológica. Fotos: Maria da Glória Motta Garcia.

\subsection{AS “PILLOW-LAVAS" DE PIRAPORA DO BOM JESUS}

Outra iniciativa que merece destaque está sendo realizada em Pirapora do Bom Jesus, pequena cidade que fazia parte da antiga rota dos Bandeirantes. Além de outros atrativos, a região apresenta potencial para desenvolvimento do geoturismo, com destaque para as exposições de rochas ígneas de composição basáltica com estruturas almofadadas ("pillow-lavas"), de grande interesse para os geocientistas. Segundo Boggiani (2010), o projeto de preservação foi organizado por alunos e professores do LiGEA/Instituto de Geociências-USP e resultou numa Praça Geológica onde foi instalado um painel explicando, em linguagem adequada a um público leigo, essa feição geológica incomum (Figura 32).

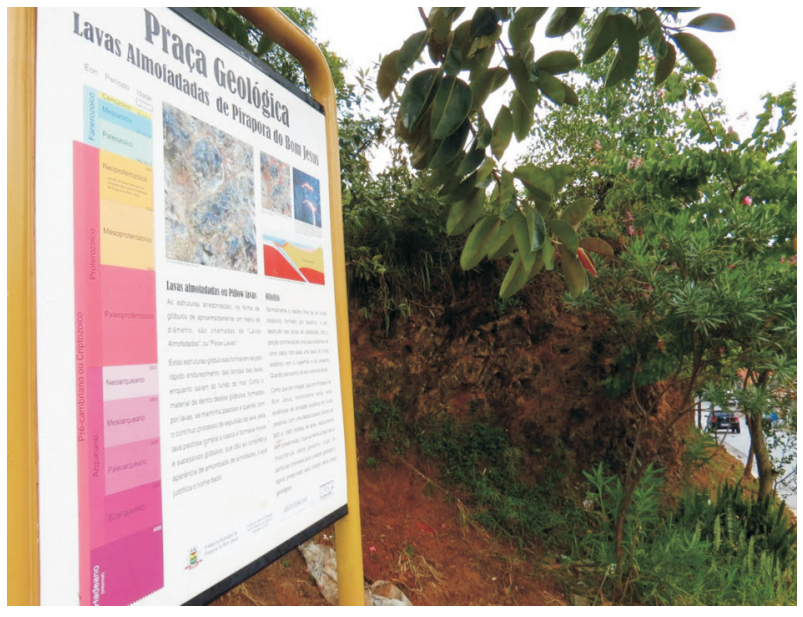

Figura 32 - Painel informativo em Pirapora do Bom Jesus (LiGEA/IGc-USP), de autoria de E. G. Nakashima. Foto: André Bonacin.

\subsection{SIGEP e GEOSSIT}

A SIGEP (Comissão Brasileira de Sítios Geológicos e Paleobiológicos) foi a iniciativa pioneira na identificação e catalogação de sítios do patrimônio geológico numa escala nacional; hoje está sob a administração da CPRM. Já publicou dois volumes impressos, e o terceiro está em preparo. A versão online é um portal dinâmico, cujas informações atualizadas podem ser a qualquer momento conhecidas no site sigep.cprm.gov.br/. Esses projetos cobrem todo o país, mas a Tabela I mostra apenas a situação dos sítios catalogados no Estado de São Paulo até o mês de junho de 2013, apresentando a respectiva etapa de catalogação e divulgação nos Volumes I e II (já impressos), na versão pré-print do Volume III, e online. 


\begin{tabular}{|c|c|c|c|c|}
\hline $\begin{array}{l}\text { Sítio } \\
\text { № }\end{array}$ & $\begin{array}{c}\text { Título SIGEP } \\
\text { (Nome do sítio) }\end{array}$ & $\begin{array}{l}\text { Subtítulo SIGEP } \\
\text { (Descrição sucinta) }\end{array}$ & $\begin{array}{c}\text { Situação em } \\
\text { junho de } 2013\end{array}$ & $\begin{array}{c}\text { Endereço da } \\
\text { Informação online }\end{array}$ \\
\hline 013 & $\begin{array}{l}\text { Icnofósseis da } \\
\text { Usina Porto } \\
\text { Primavera }\end{array}$ & $\begin{array}{l}\text { Rastros de dinossauros e de } \\
\text { mamíferos em rochas do } \\
\text { deserto neocretáceo Caiuá }\end{array}$ & Vol. II - impresso & sigep.cprm.gov.br/sitio013/sitio013.pdf \\
\hline 021 & $\begin{array}{l}\text { Rocha } \\
\text { Moutonnée } \\
\text { de Salto }\end{array}$ & $\begin{array}{l}\text { Típico registro } \\
\text { de abrasão glacial do } \\
\text { Neopaleozoico }\end{array}$ & Vol. I - impresso & sigep.cprm.gov.br/sitio021/sitio021.htm \\
\hline 032 & $\begin{array}{l}\text { Sítio Fossilífero } \\
\text { de } \\
\text { Pirapozinho }\end{array}$ & $\begin{array}{l}\text { Extraordinário depósito } \\
\text { de } \\
\text { quelônios do Cretáceo }\end{array}$ & Vol. I - impresso & sigep.cprm.gov.br/sitio032/sitio032.htm \\
\hline 035 & $\begin{array}{l}\text { Pavimento } \\
\text { Estriado } \\
\text { Guaraú, Salto }\end{array}$ & $\begin{array}{c}\text { Marcas de geleira } \\
\text { neopaleozoica no sudeste } \\
\text { brasileiro }\end{array}$ & Vol. II - impresso & sigep.cprm.gov.br/sitio035/sitio035.pdf \\
\hline 043 & $\begin{array}{l}\text { Carste e Cavernas } \\
\text { do Parque Estadual } \\
\text { Turístico do } \\
\text { Alto Ribeira } \\
\text { (PETAR) }\end{array}$ & $\begin{array}{c}\text { Sistemas de cavernas com } \\
\text { paisagens subterrâneas } \\
\text { únicas }\end{array}$ & Vol. I - impresso & sigep.cprm.gov.br/sitio043/sitio043.htm \\
\hline 049 & $\begin{array}{l}\text { Estromatólitos de } \\
\text { Nova Campina e } \\
\text { Itapeva }\end{array}$ & $\begin{array}{l}\text { Primeiros estromatólitos } \\
\text { descritos na } \\
\text { América do Sul }\end{array}$ & Vol. III - pré-print & sigep.cprm.gov.br/sitio049/sitio049.pdf \\
\hline 053 & $\begin{array}{l}\text { Répteis Fósseis } \\
\text { de } \\
\text { General Salgado }\end{array}$ & $\begin{array}{l}\text { Registro de transformações } \\
\text { ambientais na Bacia Bauru } \\
\text { durante o Cretáceo }\end{array}$ & Vol. III - pré-print & sigep.cprm.gov.br/sitio053/sitio053.pdf \\
\hline 055 & $\begin{array}{l}\text { Pedra do Baú, } \\
\text { São Bento } \\
\text { do Sapucaí }\end{array}$ & $\begin{array}{c}\text { Imponente relevo residual na } \\
\text { superfície de erosão } \\
\text { Gondwana }\end{array}$ & Vol. III - pré-print & sigep.cprm.gov.br/sitio055/sitio055.pdf \\
\hline 062 & Varvito de Itu & $\begin{array}{l}\text { Registro clássico } \\
\text { da glaciação } \\
\text { neopaleozoica }\end{array}$ & Vol. I - impresso & sigep.cprm.gov.br/sitio062/sitio062.htm \\
\hline 078 & $\begin{array}{l}\text { Fazenda } \\
\text { Santa Fé } \\
\text { (Tremembé) }\end{array}$ & $\begin{array}{l}\text { A maior associação } \\
\text { de fósseis } \\
\text { do Terciário brasileiro }\end{array}$ & Vol. I - impresso & sigep.cprm.gov.br/sitio078/sitio078.htm \\
\hline 079 & $\begin{array}{l}\text { Jazigo Icnofossilífero } \\
\text { do Ouro } \\
\text { (Araraquara) }\end{array}$ & $\begin{array}{l}\text { Ricas pistas de } \\
\text { tetrápodes do } \\
\text { Jurássico }\end{array}$ & Vol. I - impresso & sigep.cprm.gov.br/sitio079/sitio079.htm \\
\hline 080 & $\begin{array}{l}\text { Escarpamento } \\
\text { Estrutural } \\
\text { Furnas }\end{array}$ & $\begin{array}{l}\text { Raro sítio } \\
\text { geomorfológico } \\
\text { brasileiro }\end{array}$ & Vol. I - impresso & sigep.cprm.gov.br/sitio080/sitio080.htm \\
\hline 087 & $\begin{array}{l}\text { Jazigo Rodovia } \\
\text { Quiririm-Campos } \\
\text { do Jordão, } \\
\text { km } 11 \\
\text { (Tremembé) }\end{array}$ & $\begin{array}{c}\text { Macrofósseis vegetais } \\
\text { do } \\
\text { Terciário }\end{array}$ & Vol. I - impresso & sigep.cprm.gov.br/sitio087/sitio087.htm \\
\hline 098 & $\begin{array}{l}\text { Cavas de Ouro } \\
\text { Históricas do } \\
\text { Jaraguá }\end{array}$ & $\begin{array}{l}\text { Os primórdios } \\
\text { da mineração } \\
\text { no Brasil }\end{array}$ & Vol. I - impresso & sigep.cprm.gov.br/sitio098/sitio098.htm \\
\hline
\end{tabular}


Neto et al./Boletim Paranaense de Geociências 70 (2013) 53-76

\begin{tabular}{|c|c|c|c|c|}
\hline $\begin{array}{l}\text { Sítio } \\
\text { № }\end{array}$ & $\begin{array}{l}\text { Título SIGEP } \\
\text { (Nome do sítio) }\end{array}$ & $\begin{array}{l}\text { Subtítulo SIGEP } \\
\text { (Descrição sucinta) }\end{array}$ & $\begin{array}{l}\text { Situação em } \\
\text { junho de } 2013\end{array}$ & $\begin{array}{l}\text { Endereço da } \\
\text { Informação online }\end{array}$ \\
\hline 116 & Cratera de Colônia & $\begin{array}{l}\text { Provável astroblema } \\
\text { com registros do } \\
\text { paleoclima } \\
\text { quaternário na Grande } \\
\text { São Paulo }\end{array}$ & Vol. II - impresso & sigep.cprm.gov.br/sitio116/sitio116.pdf \\
\hline 125 & $\begin{array}{c}\text { Campo de } \\
\text { Estromatólitos } \\
\text { Gigantes de } \\
\text { Santa } \\
\text { Rosa de Viterbo }\end{array}$ & $\begin{array}{c}\text { Excelente registro } \\
\text { do litoral } \\
\text { do mar permiano Irati, } \\
\text { Bacia } \\
\text { do Paraná }\end{array}$ & Vol. II - impresso & sigep.cprm.gov.br/sitio125/sitio125.pdf \\
\hline- & $\begin{array}{l}\text { Cones de } \\
\text { hidrotermalito silicoso } \\
\text { de Anhembi }\end{array}$ & $\begin{array}{l}\text { Não tem (N.A.: são milhares } \\
\text { de cones silicosos ao meio } \\
\text { de sedimentos finos e } \\
\text { margosos do Permiano da } \\
\text { Bacia do Paraná) }\end{array}$ & Minuta - Revisão & $\begin{array}{c}\text { sigep.cprm.gov.br/propostas/Geyseritos } \\
\text { PermianosAnhembiSP.htm }\end{array}$ \\
\hline- & $\begin{array}{l}\text { Lavas Almofadadas } \\
\text { de Piraporado Bom } \\
\text { Jesus, SP }\end{array}$ & $\begin{array}{l}\text { Evidência de atividade } \\
\text { vulcânica formadora } \\
\text { de crosta oceânica } \\
\text { às margens do } \\
\text { Rio Tietê }\end{array}$ & $\begin{array}{l}\text { Proposta } \\
\text { aprovada }\end{array}$ & $\begin{array}{c}\text { sigep.cprm.gov.br/propostas/Lavas_- } \\
\text { almofadadas_Pirapora_Bom_Jesus_SP. } \\
\text { htm }\end{array}$ \\
\hline- & $\begin{array}{l}\text { Marundito do } \\
\text { Pico Pelado, } \\
\text { Guarulhos }\end{array}$ & $\begin{array}{l}\text { Vestígios de mineralizações } \\
\text { de ouro em mar } \\
\text { mesoproterozoico }\end{array}$ & $\begin{array}{l}\text { Proposta } \\
\text { aprovada }\end{array}$ & $\begin{array}{l}\text { sigep.cprm.gov.br/propostas/Marundito } \\
\text { _Pico_Pelado_Guarulhos_SP.htm }\end{array}$ \\
\hline- & $\begin{array}{l}\text { Paleolagunas na } \\
\text { Estação Ecológica } \\
\text { Juréia-Itatins }\end{array}$ & $\begin{array}{l}\text { Não tem (N.A.: Sítio de } \\
\text { interesse paleoambiental, } \\
\text { sedimentar, estratigráfico e } \\
\text { geomorfológico, com } \\
\text { vestígios arqueológicos) }\end{array}$ & $\begin{array}{l}\text { Proposta } \\
\text { aprovada }\end{array}$ & $\begin{array}{c}\text { sigep.cprm.gov.br/propostas/Estacao_ } \\
\text { Ecologica_Jureia_Itatins.htm }\end{array}$ \\
\hline- & $\begin{array}{l}\text { Turfeira da Campina } \\
\text { do Encantado, } \\
\text { Pariquera-Açu }\end{array}$ & $\begin{array}{c}\text { Não tem (N.A.: Sítio de } \\
\text { interesse paleoambiental, } \\
\text { sedimentar, estratigráfico e } \\
\text { paleontológico, com } \\
\text { vestígios arqueológicos) }\end{array}$ & $\begin{array}{l}\text { Proposta } \\
\text { aprovada }\end{array}$ & $\begin{array}{l}\text { sigep.cprm.gov.br/propostas/Turfeira_ } \\
\text { Campina_Encantado_SP.htm }\end{array}$ \\
\hline
\end{tabular}

Tabela 1 - Situação dos sítios do Estado de São Paulo catalogados no SIGEP até junho de 2013, apresentando a etapa da respectiva catalogação e divulgação nos Volumes I III, já impressos, na versão pré-print do Volume III, e online.

O GEOSSIT (Sistema de Cadastramento e Quantificação de Geossítios) é um aplicativo inovador, recém-disponibilizado online pela CPRM, de livre consulta, destinado ao inventário, qualificação e valoração quantitativa de geossítios. Com o passar do tempo, os geossítios paulistas serão inseridos nesse sistema. Seu site é www.cprm.gov.br/geossit/.

\section{PERSPECTIVAS DE INVENTÁRIO DO PATRIMÔNIO GEOLÓGICO NATURAL PAULISTA}

A inexistência de uma estratégia de conservação do patrimônio geológico definida para o Estado de São Paulo dificulta os trabalhos de identificação, inventário e quantificação dos geossítios, e consequentemente a implantação de novas políticas públicas voltadas à conservação do patrimônio natural geológico. Tal deficiência é recorrente em nível nacional e as iniciativas existentes são geralmente frutos de esforço pessoal, de caráter localizado. Lima (2008) apresentou uma proposta para a sistematização do inventário do patrimônio geológico brasileiro. Esta proposta, que pode ser livremente adotada, de maneira voluntária, pelos estados, requer destes entes federativos os seguintes passos:

a) definição do objetivo do inventário;

b) organização de grupos de trabalho;

c) revisão bibliográfica;

d) identificação e caracterização dos contextos 
geológicos;

e) identificação dos geossítios para cada contexto geológico;

f) caracterização dos geossítios.

Apesar de ter sido o primeiro estado a criar um conselho para gerir o patrimônio geológico, São Paulo ainda carece de uma articulação satisfatória que envolva instituições de pesquisa e ensino, equipe de especialistas e recursos para realizar o inventário sistemático de todo o seu território, fundamental para embasar diversas políticas públicas voltadas para a gestão desse patrimônio. Esse quadro, entretanto, pode mudar com o recém lançado Projeto "Inventário do Patrimônio Geológico Paulista", organizado pelo Instituto de Geociências da USP em parceria com a Universidade do Minho, Portugal e com o apoio do Programa Ciência sem Fronteiras, do governo federal (MEC/CAPES/CNPq). O projeto tem como objetivo realizar o inventário sistemático do patrimônio geológico do Estado, utilizando para isso as bases da metodologia aplicada em Portugal, com as devidas adaptações ao nosso território. Com isso, São Paulo poderá vir a ser o primeiro estado brasileiro a contar com um inventário de seu patrimônio.

\section{PATRIMÔNIO GEOLÓgICO CONSTRUÍDO E MUSEALIZADO}

As discussões sobre patrimônio e particularmente a abrangência do conceito de "Patrimônio Geológico" são parte do momento atual do meio geocientífico brasileiro, e portanto é conveniente explicar como esses termos serão aqui utilizados. Por analogia com alguns conceitos das áreas de estudos do patrimônio e de museologia (ver, entre outros, Lima, 2012 e vários itens de sua lista de referências), serão aqui adotadas duas expressões ainda não muito comuns no meio geocientífico - salvo, e mesmo assim não com muita frequencia, na comunidade dedicada exatamente ao tema do patrimônio geológico. A expressão "patrimônio geológico construído" será usada em referência a elementos da geodiversidade, de qualquer origem, que tenham sido incorporados, seja como base, componente estrutural ou componente decorativo, a construções e produtos de vários tipos - na maioria dos casos imóveis, monumentos, túmulos ou estátuas. A expressão "patrimônio geológico musealizado", designará elementos da geodiversidade colocados sob a tutela de um museu, lembrando que isso pode ocorrer seja pela remoção do elemento de sua localização original e transporte ao espaço físico do museu (por exemplo, a placa de calcário da Figura 8), seja pela manutenção do elemento na sua localização original, à qual se aplicará a tutela do museu, constituindo-se a musealização in situ (prática comum em arqueologia, mas no estado de São Paulo ainda muito incipiente na paleontologia e inexistente para a preservação de outros elementos do patrimônio geológico).

O patrimônio geológico construído e o musealizado podem apresentar-se sob diversas formas, e estão com mais frequência associados a ambientes urbanos. Apesar de meio urbano ser na maioria dos casos dissociado da geologia tradicional, vários autores (e.g. Stern et al., 2006; Liccardo et al, 2008; Del Lama et al, 2009; Liccardo et al., 2012) defendem que, pelas facilidades oferecidas - em particular a proximidade e as facilidades de acesso a baixo custo, que estimulam a visitação por turistas e estudantes - esse é um caminho privilegiado para aproximar o público da geologia.

Os elementos possíveis de serem enquadrados como patri môni o geo lóg ico const ruí do são potencialmente muito variados e incluem principalmente: elementos geológicos in situ porém retrabalhados por obras, como áreas de antigas pedreiras; e rochas utilizadas na construção civil, em monumentos, estatuária e em cemitérios. Um tipo particular de patrimônio geológico construído - e que na maior parte dos casos está fora do ambiente urbano - é o ligado a atividades de mineração, indo desde o local de minas até eventuais instalações e equipamentos conservados.

No estado de São Paulo, até o momento, o patrimônio geológico musealizado limita-se a espécimes (rochas, minerais e fósseis) expostos em museus.

O estudo do patrimônio geológico construído normalmente inclui a aproximação com outras áreas de conhecimento, particularmente a Arquitetura e a História. Essa interligação trabalha nos dois sentidos, enriquecendo o conhecimento integrado; esse é um excelente caminho de divulgação das geociências, e particularmente da geologia, a qual é reconhecida como uma ciência ainda distante da sociedade (Martini et al., 2012, pg. 187). Conceitualmente, o turismo geológico pode ser entendido como um tipo de turismo cultural, pois, segundo o ICOMOS (1996), "turismo cultural é o tipo de turismo cujo objetivo é, entre outros, a descoberta de monumentos e sítios."

No Estado de São Paulo, há duas cidades com estudos e publicações sobre aspectos do patrimônio geológico construído: a Capital e a cidade de Rio Claro. Um guia com aspectos do geoturismo e de locais históricos das cidades de Santos e São Vicente, impresso na forma de folheto, foi apresentado e distribuído no 46으 Congresso Brasileiro de Geologia, em 2012 (MantessoNeto et al., 2012).

\subsection{PATRIMÔNIO GEOLÓGICO CONSTRUÍDO NA CIDADE DE SÃO PAULO, AO AR LIVRE}

Roteiros geoturísticos para o chamado "centro velho" de São Paulo já foram propostos por Stern et al. (2006), Augusto \& Del Lama (2011), e Rodrigues (2012). 
praticamente toda a cidade - na realidade, pouco mais do que uma vila, com suas construções em taipa, e raros imóveis tendo mais de dois pisos. Nessa época, com a riqueza proporcionada pelo café, inicia-se a transformação em uma cidade moderna, com o uso de novos materiais - e inicia-se exatamente por essa região, atualmente chamada de "Centro Velho", explicando-se assim a concentração nessa área de inúmeros monumentos e edifícios nos quais a pedra entra como elemento de construção ou decoração.

Apesar de muitas das rochas utilizadas serem importadas, principalmente da Itália e de Portugal, há também muitas rochas brasileiras, particularmente paulistas. Entre essas, destacam-se o Granito Itaquera e o Granito Cinza Mauá, o primeiro mais usado no começo do século XX e o segundo, a partir da década de 40 desse mesmo século (Del Lama et al., 2009).

Num percurso pelos principais edifícios e monumentos históricos que compõem o Centro Velho podem ser visualizadas as seguintes rochas: Granito Itaquera, Granito Cinza Mauá, Granito Rosa Itupeva, Granito Verde Ubatuba, Granito Preto Piracaia, Granito Azul Bahia, Calcário Sete Lagoas, Arenito Itararé, Cipollino, Porfido Rosso Antico, microbialito, travertino, conglomerado, calcário fossilífero, serpentinito, mármore e sienito. No cômputo geral, as rochas ígneas, principalmente os granitos, foram as preferidas.

O Obelisco da Memória (Figura 33), construído em 1814, o monumento mais antigo da cidade, é lavrado em Granito Itaquera, uma das rochas que veio a ser mais utilizada, sendo observada em vários monumentos e edifícios.

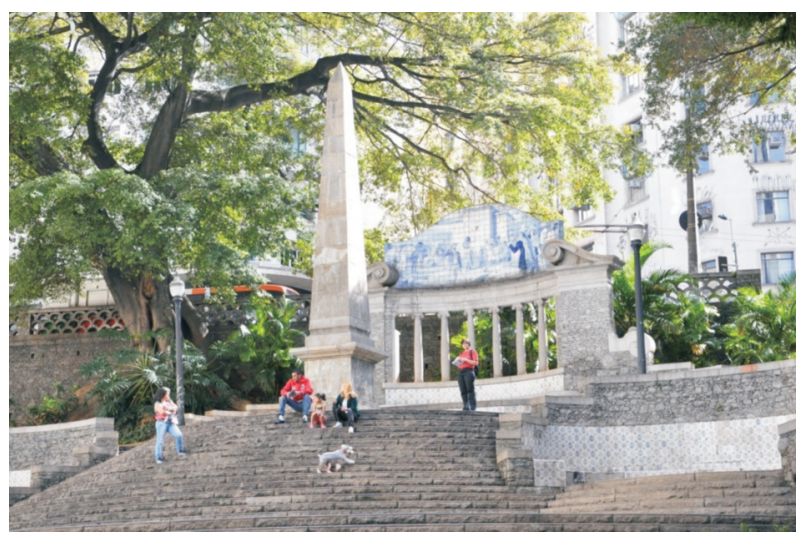

Figura 33 - O monumento mais antigo da cidade de São Paulo Obelisco da Memória (1814). É constituído pelo Granito Itaquera, e a escadaria implantada no século XX é constituída pelo Granito Cinza Mauá. Foto: Lauro Kazumi Dehira.
O Granito Cinza Mauá foi, e ainda é, muito utilizado em São Paulo, como pode ser visto em boa parte do revestimento do piso do Centro Velho e em muitas estações do metrô. Apesar de estar localizado um pouco distante do Centro Velho, um dos cartões postais da cidade, o Monumento às Bandeiras, é constituído por este granito (Figura 34).

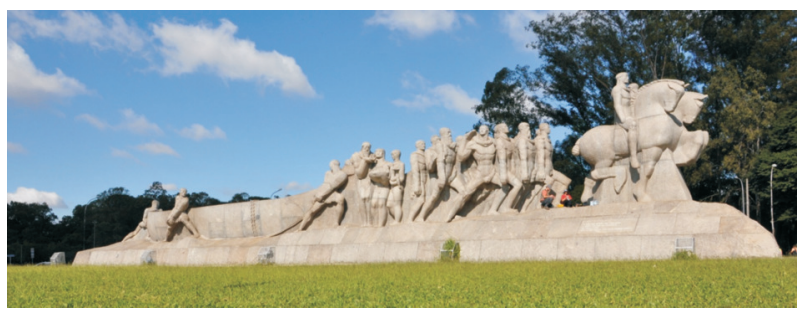

Figura 34 - O Monumento às Bandeiras, de Victor Brecheret, esculpido em Granito Cinza Mauá, levou 6 anos para ser finalizado e foi implantado em 1953, para as comemorações do IV Centenário da cidade ( 25 de janeiro de 1954). Foto: Lauro Kazumi Dehira.

Rochas sedimentares foram pouco utilizadas nas construções do Centro Velho. Destacamos aqui a fachada do Teatro Municipal e a Prefeitura Municipal de São Paulo. O teatro (Figura 35) é constituído pelo Arenito Itararé, proveniente da área da atual Flona (Floresta Nacional) de Ipanema. $\mathrm{O}$ atual prédio da Prefeitura, em estilo neoclássico de inspiração fascista, foi concluído em 1938/39, para ser a sede do então poderoso grupo Indústrias Reunidas Francisco Matarazzo; sua fachada é revestida, segundo consta (Folha de S. Paulo, 2004) por 170.000 placas de travertino italiano (Figura 36). O mesmo tipo de rocha também é encontrada em vários edifícios comerciais e residenciais do Centro Velho.

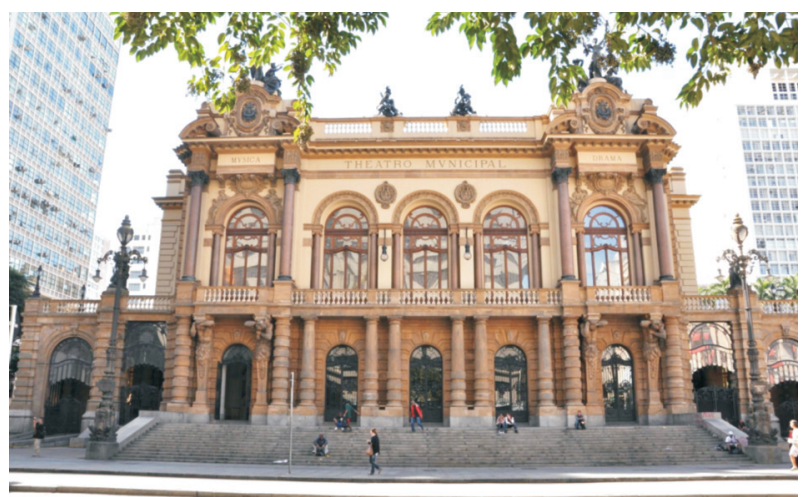

Figura 35 - Teatro Municipal de São Paulo (inaugurado em 1911), fachada frontal em Arenito Itararé e base de Granito Itaquera. Foto: Lauro Kazumi Dehira. 


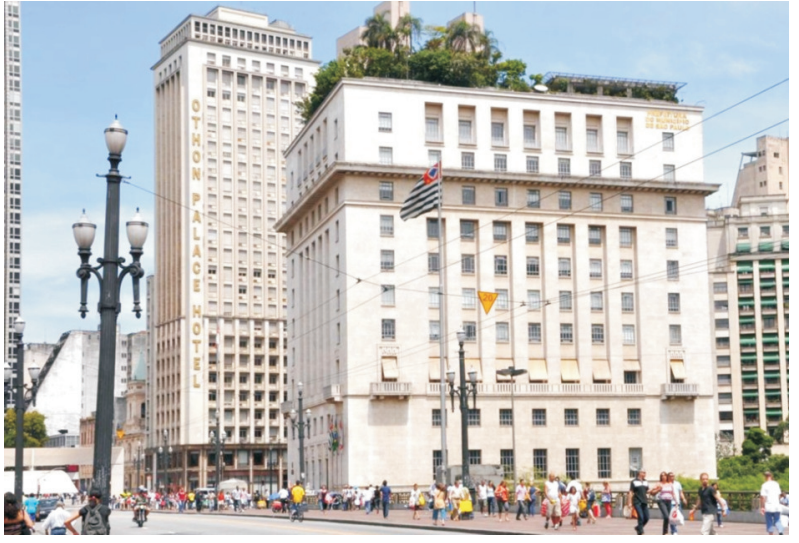

Figura 36 - Prefeitura do Município de São Paulo (prédio de 1938), imóvel revestido por travertino italiano. Foto: Lauro Kazumi Dehira.

As rochas metamórficas foram mais utilizadas em interiores e em monumentos, sendo a mais destacada o mármore, particularmente o que é considerado o mais "nobre" deles para fins de estatuária, o de Carrara, que ocorre em grande parte das fontes e monumentos da cidade.

\subsection{PROBLEMAS E PROTEÇÃO DE MONUMENTOS NA CIDADE DE SÃO PAULO}

Infelizmente, o que se constata é que o estado de conservação da maioria dos monumentos de São Paulo não é bom. Como são relativamente recentes, a alteração intempérica teve pouca influência na sua degradação. Sem dúvida, o principal fator de degradação dos monumentos é o vandalismo: pichações, quebras, roubo de partes, uso inadequado.

Um triste exemplo dos desafios encontrados é a fonte situada na Praça Júlio de Mesquita. Inaugurada em 1927, em plena euforia do café, como marco de modernismo da cidade, enfrentou as últimas décadas em um clima de degradação urbana, incluindo queda de atividades comerciais, queda do valor e eventual estado de abandono de imóveis, presença constante de uma população de moradores em situação de rua, tráfico de drogas, e uso da base da fonte como, praticamente, banheiro público. Originalmente a fonte tinha entre seus elementos de decoração 4 faces mitológicas femininas e várias lagostas de bronze, cada peça com cerca de $1 \mathrm{~m}$ de altura, que foram quase todas roubadas. O mármore foi acentuadamente atacado pela urina humana e de animais de companhia. Num projeto de preservação, a Prefeitura concluiu em meados de 2013 um trabalho de restauro da fonte, recolocou - agora feitas de fibra de vidro - as faces femininas e as lagostas (localmente muitas vezes chamadas de "aranhas" ou "caranguejos") e instalou ao seu redor uma estrutura de pilares de metal e painéis de vidro, formando uma espécie de "aquário". Esta solução não é uma invenção local; é usada para proteger monumentos, e mesmo geossítios, em diversos locais do mundo. Como parte também de um programa de recuperação social da área central da cidade, foi estabelecida na praça uma base de policiamento da Guarda Civil Metropolitana (Figura 37).

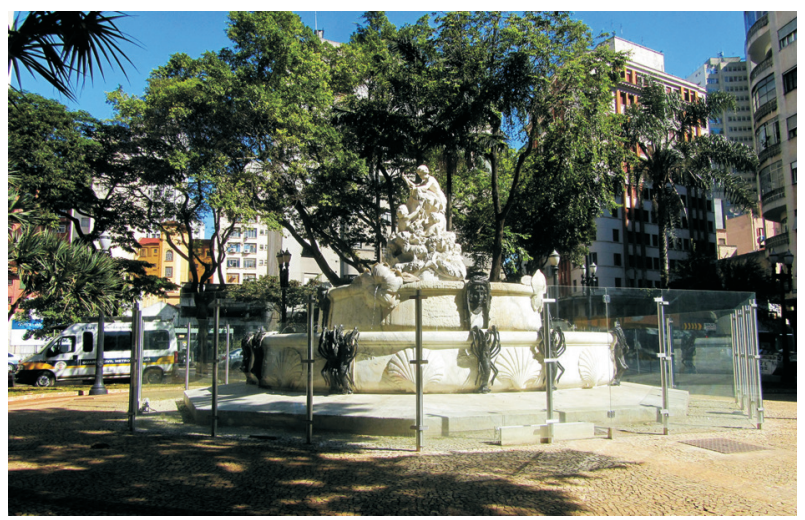

Figura 37 - Fonte Monumental, instalada em 1927, na Praça Júlio de Mesquita. Confeccionada em mármore de Carrara, com elementos decorativos originalmente em bronze, hoje em fibra de vidro. Proteção tipo "aquário" instalada em meados de 2013, após restauro ou substituição de todos os elementos da fonte. Notar, à esquerda, veículo da Guarda Civil Metropolitana, em plantão permanente. Foto: Virginio Mantesso-Neto.

Existem outros exemplos de monumentos esculpidos em rocha, e vários imóveis com fachadas em rocha, partes de um patrimônio geológico construído, em lastimável situação de (falta de) preservação. Há também outros casos de cercamento de monumentos, como o da Amizade Sírio-Libanesa, do Duque de Caxias e o de Camões.

Este não deveria ser um padrão para a conservação de monumentos mas infelizmente é uma opção até que se consiga tornar realidade um trabalho de educação patrimonial mostrando a importância destas obras para a preservação da história da cidade, e que diversos outros desafios sociais sejam superados.

\subsection{HISTÓRIA GEOLÓGICA DO CENTRO DE RIO CLARO}

Além dos resultados do projeto descrito no item 4.2, Perinotto (2009) publicou um excelente trabalho aproximando geologia, história, e vida cotidiana, fazendo uma "demonstração de como as paisagens se sucederam ao longo do tempo geológico na cidade de Rio Claro e região" (pg. 187). Após uma breve introdução de conceitos geológicos (tempo geológico, estratigrafia, evolução biológica, coluna estratigráfica, descrição das unidades, etc.), o trabalho foca-se no centro da cidade (Praça da Liberdade) e ilustra, com fotos de ambientes atuais similares, o que seria o aspecto do seu entorno ao tempo da deposição de cada unidade da coluna estratigráfica local, concluindo com o período da história humana.

Esse tipo de trabalho de divulgação científica pode ser um elemento auxiliar na formação de futuras 
gerações com maior consciência preservacionista, componente cada vez mais protagonista de uma cidadania plena e responsável. Uma contextualização mais ampla desse potencial é discutida por Perinotto \& Mantesso-Neto (2013a e 2013b).

\subsection{SHOPPING CENTERS COMO ELEMENTOS DO PATRIMÔNIO GEOLÓGICO CONSTRUÍDO}

A proliferação de shopping centers, tanto na Capital quanto nas cidades do interior do estado, é uma tendência comercial e urbanística absolutamente estabelecida. A ABRASCE, Associação Brasileira de Shopping Centers, estima que atualmente existam 165 no estado, sendo 54 na Capital; em outras palavras, 2/3 deles estão no interior (ABRASCE, 2013).

Nos shoppings centers as rochas ornamentais são muito utilizadas, tanto nas áreas comuns, quanto nas unidades comerciais. As áreas são em geral muito amplas, e a escolha frequentemente recai sobre a combinação de diversos tipos de rocha, que permitem soluções estéticas interessantes, pelo uso de rochas com estruturas bastante vistosas, contraste de cores e formação de desenhos com padrões muito variados.

Por esses vários motivos, os shoppings centers têm potencial para tornar-se locais de destaque dentro da já mencionada possibilidade de usar elementos urbanos como fatores de aproximação do público leigo às geociências; sobre essa possibilidade, ver, por exemplo, Sallun Filho \& Fairchild (2005).

\subsection{ARTE CEMITERIAL, OU FUNERÁRIA, OU TUMULAR}

Em várias cidades do mundo os cemitérios são incluídos nas listas de atrações turísticas, inclusive com visitas guiadas que em alguns deles são muito frequentadas. Osman \& Ribeiro $(2007$, p. 3) atestam que o cemitério é "um ponto turístico consolidado nos mais diferentes países do mundo". Entre nós, esse patrimônio só recentemente começou a ser valorizado, e os mais interessantes são aqueles datados de um período que vai desde aproximadamente meados do século XIX até meados do século XX.

Além do valor histórico e de veneração à memória de personalidades importantes, no estado de São Paulo muitos deles são quase que verdadeiros museus a céu aberto, com acervos importantes principalmente de pequenas obras arquitetônicas e de esculturas. Parte destas é em bronze, mas boa parte é de esculturas em rochas. As rochas presentes podem ser da própria região, ou vir praticamente de qualquer lugar do mundo; uma altamente valorizada é o mármore de Carrara.

A arte tumular pode ser utilizada para geoturismo de diversas maneiras. As rochas utilizadas são muito variadas, e podem apresentar superfícies de fratura bruta, ou superfícies polidas (às vezes ambas, combinadas em diferentes partes do túmulo), e apresentar cantos (triedros), permitindo boa visualização tridimensional de algumas características. $O$ estado atual dela pode permitir observações interessantes sobre a questão do intemperismo, com a vantagem de apresentar uma data inicial desse processo; já existem estudos sobre esse tema, por exemplo os de Kuzmickas \& Del Lama (2008 e 2009).

Indo para o universo de outros saberes, pode-se associar os túmulos, as estátuas e o material utilizado a questões de moda, de demonstração de riqueza e de poder, ao estilo artístico do escultor, às maneiras como a morte foi encarada em diferentes momentos e por diferentes grupos sociais, às diferenças na composição étnica da camada mais rica da sociedade paulistana.

Na cidade de São Paulo quatro cemitérios são particularmente ricos em esculturas pétreas. O da Consolação, primeiro cemitério civil da cidade, inaugurado em 1858, o do Araçá, inaugurado em 1887, e o São Paulo, de 1926, estavam entre os preferidos pela classe econômica mais alta. O Cemitério do Brás (Quarta Parada), inaugurado em 1893, é o segundo maior em área dentre os inaugurados no século XIX; apesar do nível econômico das famílias sepultadas ser inferior aos três outros citados, tem a peculiaridade de ter servido à maior comunidade de imigrantes da cidade, a italiana. Como os cemitérios na Itália costumavam ter muitas estátuas e a quase totalidade dos escultores de estátuas em São Paulo era constituída de italianos (Giovannetti Neto, 1992, passim), esse cemitério tem um acervo muito grande de estátuas, apesar destas serem, no geral, menores que nos outros três. Para o Cemitério da Consolação há um Roteiro Geológico (Kuzmickas \& Del Lama, 2011). Um estudo bastante aprofundado sobre as rochas ornamentais utilizadas no Cemitério da Consolação, suas diversas formas de alteração e recomendação para a conservação dos jazigos pode ser encontrado em Kuzmickas (2013).

No interior do estado, há diversos cemitérios interessantes, principalmente ao longo dos eixos ferroviários que caracterizaram o ciclo do café, favorecidos pela combinação da riqueza gerada pelo "ouro verde" com a presença de imigrantes italianos, que, no cômputo geral, constituem o maior conjunto de escultores que atuaram também no âmbito geográfico do estado. Alguns exemplos, sobre os quais há estudos em dissertações de mestrado e teses de doutoramento, livros publicados ou sites na Internet, são os de Campinas (Saudade), Jundiaí (Nossa Senhora do Desterro), Ribeirão Preto (Saudade), Piracicaba (Saudade), Rio Claro (São João Batista), São João da Boa Vista (São João Batista) e Santos (Paquetá).

\subsection{MUSEUS GEOLÓGICOS}

Os museus, particularmente os especializados (geológicos, mineralógicos ou paleontológicos) são uma 
componente importante de preservação do patrimônio geológico. Existem diversos deles no estado de São Paulo. Além do acervo específico de minerais, rochas e fósseis, alguns ampliam sua atratividade incluindo seções de espeleologia, de gemologia, de arqueologia, e atrações como esqueletos de dinossauros, loja de souvenirs com venda de livros, minerais e réplicas de fósseis. A maior parte deles oferece, mediante agendamento, visitas guiadas específicas para diversas faixas etárias, ou para grupos de escolares, associações, e outros. Os principais museus paulistas que abrigam itens do patrimônio geológico são: Museu Geológico Valdemar Lefèvre, do Instituto Geológico, e Museu de Geociências do Instituto de Geociências da USP, na Capital; Museu de Minerais e Rochas "Heinz Ebert", e Museu de Paleontologia e Estratigrafia "Prof. Dr. Paulo Milton Barbosa Landim", ambos do Instituto de Geociências e Ciências Exatas da UNESP, em Rio Claro; Museu de Paleontologia de Monte Alto; e Museu de História Natural de Taubaté.

Azevedo (2013) discorre sobre a conservação de coleções geológicas, abordando mais especificamente os minerais, usando como referência o Museu do Instituto de Geociências da USP.

\section{PATRIMÔNIO MINEIRO}

São relativamente poucos os itens ligados ao patrimônio mineiro no estado de São Paulo, mas alguns têm grande importância histórica.

No Vale do Ribeira existem as galerias de minas de chumbo e o Parque Morro do Ouro, já mencionados no item 4.3.

Em Araçariguama, nas proximidades da Capital, existe uma das mais antigas minas de ouro horizontais do Brasil, a Mina do Cantagalo, com uma galeria visitável e um pequeno museu.

Também sobre o ouro, deve-se destacar o Geoparque Ciclo do Ouro (Pérez-Aguilar et al., 2012 e 2013), em Guarulhos, que faz parte do livro recém publicado "Geoparques do Brasil - Propostas" (Schobbenhaus \& Silva, 2012, pg. 543-582). A área do geoparque, criado em 2008, inclui regiões das serras da Cantareira e Mantiqueira onde afloram rochas metavulcanossedimentares mesoproterozoicas do Grupo Serra do Itaberaba. Devido às mineralizações de ouro primário ocorrem muitas estruturas arqueológicas relacionadas à história mineira do primeiro Ciclo do Ouro no Brasil (Figura 38). Diversos links indicados nas Referências Bibliográficas trazem mais detalhes.

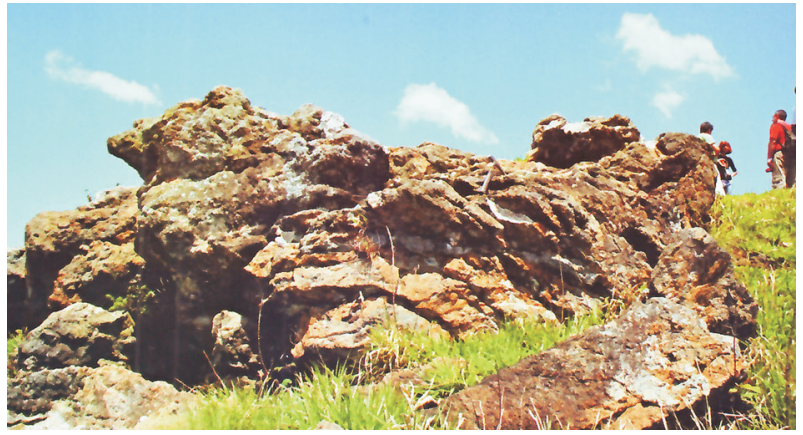

Figura 38 - Geoparque Ciclo do Ouro, Guarulhos - Afloramento de margarita-coríndon xisto (marundito) e topázio xisto (topazito) cuja gênese está associada a processos hidrotermais/metassomáticos que geraram zonas de alteração hidrotermal, as quais foram posteriormente metamorfisadas na fácies anfibolito. Por seus minerais constituintes (margarita, coríndon, topázio e rutilo), pela raridade das rochas e, por estarem vinculadas à gênese de mineralizações de ouro na região, apresentam um grande interesse científico e educacional, sendo mais um elemento de atração do Geoparque Ciclo do Ouro (Pérez-Aguilar et al., 2012).

Uma outra importante pesquisa está em andamento nas proximidades da Capital. Nos arredores do Pico do Jaraguá foram identificadas com segurança cinco cavas de mineração de ouro (Carneiro, 2000) que, ao que tudo indica, foram exploradas pela família Sardinha a partir da década de 1580. Em 1810 o inglês John Mawe visitou-as e encontrou-as em atividade, descrevendo minuciosamente o processo de lavagem do solo para separação do ouro (Mawe, 1812, p. 77-79). Nesse mesmo livro (entre as pg. 78 e 79) ele apresenta uma imagem muito interessante da "escada" usada para essa lavagem (Figura 39).

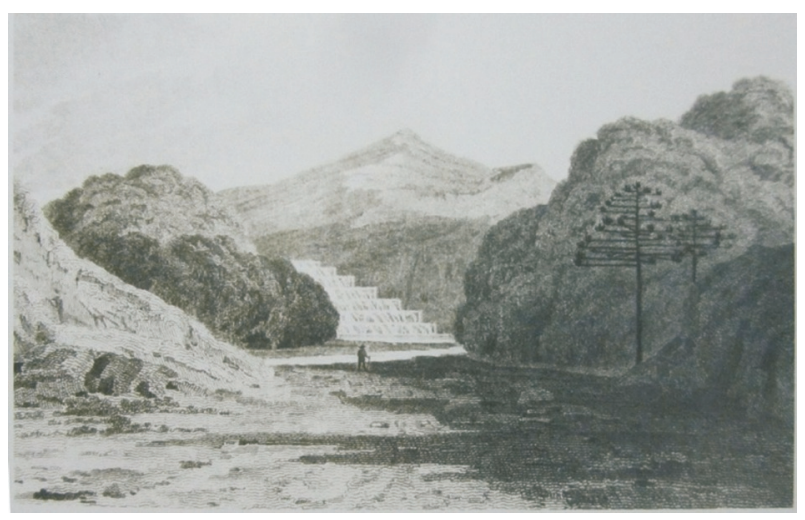

Figura 39-Gravura publicada por Mawe (1812) das escadas de lavagem do ouro, constituindo a única representação gráfica até hoje encontrada das atividades mineiras na região do Pico do Jaraguá. Estão em curso pesquisas visando a identificação exata desse local. 
A pesquisa para identificar a localização tanto quanto possível precisa dessa escada está em progresso, havendo no momento vários locais selecionados como bons candidatos (Silva, 2013). Em 1820 José Bonifácio de Andrada e Silva, então recentemente chegado de Portugal, realizou, acompanhado pelo irmão Martim Francisco, uma "Viagem mineralógica na província de São Paulo", e no seu relato refere-se às "antigas minas de ouro", nos arredores do Jaraguá, citando nominalmente cinco delas (Silva, 1963, Vol. I, pg. 510), e descrevendo aspectos de sua geologia e técnicas de retirada do ouro. Ele menciona também a existência, nas proximidades, de outras "muitas e boas minas de ouro, que estão presentemente abandonadas", sempre apresentando dados geológicos. As "minas", ou mais precisamente as cavas, eram todas trabalhadas no solo de alteração, e o ouro ocorria também em guapiaras (cascalheiras superficiais) e em diversos riachos. José Bonifácio reconheceu a associação do ouro in situ a veios de quartzo, e nos depósitos aluviais a diversos minerais (hoje genericamente chamados de "satélites"), mas não menciona nenhum trabalho de mineração nas rochas metamórficas sãs. Outros pesquisadores também falam dessas minas, como Eschwege, Calógeras, Derby, Oliveira (Prefeitura, pg. originais 6-8).

Apesar da área ter sido bastante descaracterizada (principalmente por urbanização, industrialização, abertura de estradas e obras de terraplanagem) três das cavas já identificadas estão sob um processo que visa o estabelecimento de um futuro parque, e está em andamento um pedido de tombamento pelo IPHAN. As pesquisas prosseguem, mas a geologia local sugere que trata-se da mesma mineralização presente no Geoparque Ciclo do Ouro, e também em Araçariguama. Já foram também encontradas outras áreas que preliminarmente parecem ser outras cavas similares.

$\mathrm{Na}$ questão da minerção do ferro, importantíssima por sua utilidade desde o início da presença dos portugueses no Brasil, situa-se na cidade de Iperó a antiga Fazenda Ipanema. Nesse local o pai e filho Afonso Sardinha (homônimos) estabeleceram em 1591 os dois primeiros fornos siderúrgicos do país, criando um foco de irradiação para a colonização de áreas próximas. Com altos e baixos, essas minas foram sempre uma referência e uma esperança nacionais, sendo objeto de estudos e tentativas de melhor aproveitamento, entre outros, por Varnhagen e por José Bonifácio, no final do período colonial. Durante o Segundo Reinado, a Fazenda Ipanema atingiu proporções consideráveis (Figura 40). Hoje, é sede de uma unidade de preservação ambiental (Flona Ipanema) e um dos maiores complexos industriais antigos preservados no estado.

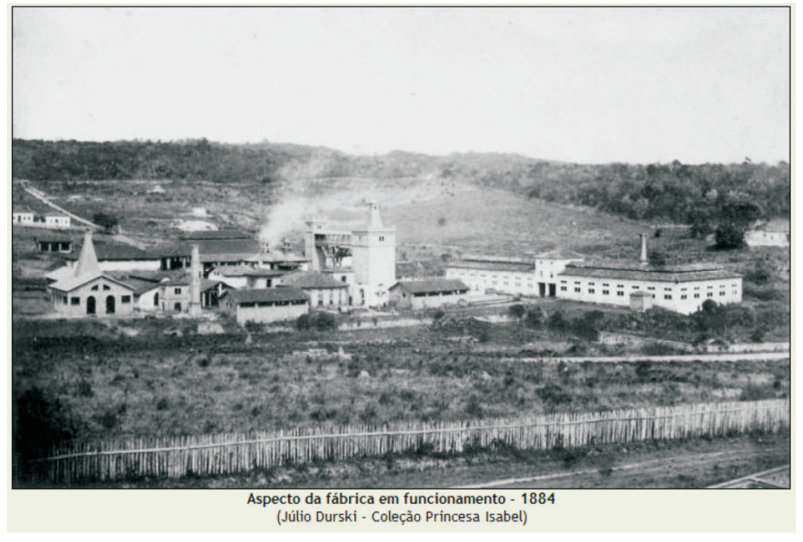

Figura 40 - A Real Fábrica de Ferro de São João de Ipanema (nome oficial) em funcionamento em 1884, durante seu período de auge, que durou aproximadamente de 1865 a 1965. (Foto: Júlio Durski, Coleção Princesa Isabel; fonte: www.cidadedeipero.com.br/ipanema.html).

Com todos esses estudos, os dois conjuntos antigos locais de mineração de ouro, e fornos de produção de ferro em Ipanema - tornam-se, tanto pela antiguidade dos sítios quanto pelo conhecimento acumulado, importantes referências do patrimônio geológico e mineiro não só do Estado de São Paulo, mas do Brasil e da própria América do Sul.

\section{CONCLUSÃO: OUTROS DESAFIOS, NOVAS FRENTES E INTERFACES}

Além das iniciativas aqui listadas, deve ser destacado o crescente interesse de professores e alunos não só das áreas de geociências, mas também das áreas de turismo, de história, e outras, nas questões de patrimônio geológico, geoturismo e afins.

Por outro lado, em regiões onde o geoturismo já tem maior tradição - particularmente na Europa - a experiência demonstra que, com raríssimas exceções, o geoturismo por si só é economicamente insustentável. "Geoturismo, como qualquer outro tipo de turismo, é uma atividade econômica. Isto significa que espera-se que essa atividade gere dinheiro que garanta uma renda sólida para investidores e trabalhadores. ... Porém, as geociências não são populares para a população em geral. ... O número de pessoas interessadas em viajar e gastar dinheiro apenas para uma atividade de turismo geológico é inquestionavelmente baixo. Naturalmente essas atividades são muito benvindas por geocientistas e por quem tem algum tipo de formação nessa área, mas a quantidade de tais pessoas é baixa demais para garantir a sustentabilidade econômica de muitas companhias de geoturismo. A ampliação do conceito de geoturismo aumentará o numero de turistas potenciais, uma tendência essencial para atingir o sucesso dessa atividade econômica" (Martini et al 2012, pg. 187). 
Para ser feita de maneira conscienciosa, a etapa inicial de todo esse processo de desenvolvimento do geoturismo deve iniciar-se pelo preparo do inventário, estudos, classificação, etc., dos geossítios e dos locais de patrimônio geológico construído, e da aplicação das medidas de segurança e proteção eventualmente necessárias. Nos momentos adequados, há três importantes caminhos práticos que podem ajudar a aumentar o volume de geoturistas:

1) investir no inventário, caracterização, proteção e divulgação do patrimônio geológico;

2) facilitar o acesso à informação e, após promover a respectiva proteção onde necessário, o acesso físico aos geossítios e aos locais de patrimônio geológico construído;

3) associar um grande número de locais de geoturismo a atividades turísticas convencionais.
Deve ser sempre lembrado que o geossítio, e mesmo os locais de patrimônio geológico construído, se caracterizam por uma total imobilidade física - ninguém consegue transportar um afloramento para colocá-lo mais perto do turista. Assim, só o terceiro caminho - que por sua vez só pode ser atingido através do primeiro e depois do segundo - permitirá a formação do que o segmento turístico chama de "clusters" (em tradução literal "cachos"), que são aglomerações de atrações turísticas relativamente próximas umas das outras, permitindo que se aproveite a presença física do turista "convencional" nas região para oferecer-lhe também, como adicional, programas e atividades geoturísticas.

Esse provavelmente será o caminho para tornar economicamente viável (ainda que, no início, apenas minimamente) a prática sistemática do geoturismo, uma ferramenta que, se bem aplicada, possibilita o bom uso do patrimônio geológico, sua fruição no presente e a sua concomitante preservação para o futuro.

\section{Referencias}

ABRASCE. 2013. Números do setor. Disponível em http://www.portaldoshopping.com.br/numeros dosetor/ grandes-numeros, passim, acesso em 28 agosto 2013.

AUGUSTO, W.C.B.; DEL LAMA, E.A. 2011. Roteiro geoturístico no centro da cidade de São Paulo. Terrae Didatica, v. 7, n. 1, p. 29-40. Disponível em: www.ige.unicamp.br/terraedidatica/v7_1/pdfv7 1/TD_7-1_3_Wilian_Batista.pdf, acesso em 28 agosto 2013 .

AZEVEDO, M.D.P. 2013. Conservação de coleções geológicas utilizando o acervo do Museu de Geociências da USP. Dissertação de Mestrado. Instituto de Geociências - USP. 199p.

AZEVEDO SOBRINHO, J.M.; JANASI, V.A.; SIMONETTI, A; HEAMAN, L.M.; SANTORO, J; DINIZ, H.N. 2011. The Ilha Anchieta Quartz Monzonite: the southernmost expression of ca. 500 Ma post-collisional magmatism in the Ribeira Belt. Anais Acad. Bras. Ciências 83(3): 891-906.

BOGGIANI, P.C., 2010. Desenvolvimento local pelo Geoturismo: preservação e divulgação das "PillowLavas" em Pirapora do Bom Jesus (SP). Projeto apresentado ao Fundo de Cultura e Extensão Universitária da Universidade de São Paulo.

CARNEIRO, C.D.R. 2000. As cavas de ouro históricas do Jaraguá. In: Schobbenhaus, C.; Campos, D.A.; Queiroz, E.T.; Winge, M.; Berbert-Born, M. (Edit.) Sítios Geológicos e Paleontológicos do Brasil. D i s p o n í v e I e m sigep.cprm.gov.br/sitio098/sitio098.htm acesso em 18 maio 2013.

DEL LAMA, E.A.; DEHIRA, L.K.; REYS, A.C. 2009. Visão geológica dos monumentos da cidade de São Paulo. Revista Brasileira de Geociências, v. 39, n. 3, p. 409-
420 D D s pon ível e m : rbg.sbgeo.org.br/index.php/rbg/article/view/1468, acesso em 26 março 2013.

ESTADO DE SÃO PAULO IMAGES. s/d. Disponível em gal1.piclab.us/key/estado\%20de\%20sao\%20paulo, acesso em 30 agosto 2013.

FOLHA DE S. PAULO. 2004. Marta inaugura amanhã nova sede da Prefeitura. Caderno cotidiano, 24 de janeiro. D i s p o n í v e I e m www1.folha.uol.com.br/fsp/cotidian/ff2401200412. htm, acesso em 30 junho 2013.

GARCIA, M.G.M., 2012. Gondwana Geodiversity and Geological Heritage: Examples from the North Coast of São Paulo State, Brazil. Anuário do Instituto de Geociências (Online).35:101-111. Disponível em www.anuario.igeo.ufrj.br/2012_1/2012_1_101_111 .pdf, acesso em 5 abril 2013.

GARCIA, M.G.M.; DEL LAMA, E.A.; MARTINS, L.; BOUROTTE, C. 2011. Geotourism potential in the North Coast of São Paulo State, Brazil: Aspects of Geoconservation, Preservation of Traditional Culture and Income Generation In: I International Geotourism Congress, Arouca-Portugal. Disponível e $\mathrm{m}$ a rqu i vo co m p a t a d o e m www.geoparquearouca.com/geotourism2011/?p=c ongress\&l=pt $>$ Panel 4 . Geotourism Destinations and Touristic Products Case Studies in Geotourism, acesso em 5 abril 2013.

GIOVANNETTI NETO, B.P. 1992. Artistas italianos nas praças de São Paulo / Artisti italiani nelle piazze di San Paolo (ed. bilíngue). Empresa das Artes, São Paulo.

ICOMOS. Charter of Cultural Tourism. Update: 13 January 1996 . Disponível e m www.icomos.org/tourism/tourism_charter.html, 
acesso em 21 março 2013.

KUZMICKAS, L. 2013. Estado de conservação dos monumentos pétreos do Cemitério da Consolação, São Paulo. Dissertação de Mestrado. Instituto de Geociências - USP. 150p.

KUZMICKAS, L.; DEL LAMA, E.A. 2008. Conservação dos monumentos pétreos do Cemitério da Consolação, São Paulo (SP). In: 44ำ Congresso Brasileiro de Geologia, Curitiba. Anais do 44을 Congresso Brasileiro de Geologia - O Planeta Terra em nossas Mãos, 2008. v. 1. p. 388-388.

KUZMICKAS, L.; DEL LAMA, E.A. 2009. Intemperismo nos monumentos pétreos do Cemitério da Consolação, São Paulo (SP). In: XI Simpósio de Geologia do Sudeste, São Pedro, SP. Anais do XI Simpósio de Geologia do Sudeste, p.129.

KUZMICKAS, L.; DEL LAMA, E.A. 2011. Roteiro Geológico pelo Cemitério da Consolação SP. In: 12 Simpósio de Geologia do Sudeste, Nova Friburgo, RJ. Anais do 12으 Simpósio de Geologia do Sudeste, 2011.

LICCARDO, A.; PIEKARZ, G.F.; SALAMUNI, E. 2008. Geoturismo em Curitiba. Curitiba: Mineropar, 122p.

LICCARDO, A.; MANTESSO-NETO, V.; PIEKARZ, G.F. 2012. Geoturismo urbano: educação e cultura. Anu. Inst. Geocienc. [online], vol.35, n.1, pp. 133-141. D i s p o n íve I e $\mathrm{m}$ : <ppegeo.igc.usp.br/scielo.php?script=sci_arttext\& $\mathrm{id}=$ S0101-97592012000100013\&lng=pt\&nrm=iso, acesso em 30 agosto 2013.

LIMA, D.F.C. 2012. Museologia-Museu e Patrimônio, Patrimonialização e Musealização: ambiência de comunhão. Bol. Mus. Para. Emílio Goeldi. Cienc. Hum., Belém, v. 7, n. 1, p. 31-50, jan.-abr. Disponível em www.scielo.br/pdf/bgoeldi/v7n1/a04v7n1.pdf, acesso em 28 agosto 2013.

LIMA, F.F. 2008. Proposta metodológica para a inventariação do Patrimônio Geológico Brasileiro. Escola de Ciências, Universidade do Minho, Portugal, Dissertação (Mestrado em Patrimônio Geológico e Geoconservação), 90p. Disponível em www.dct.uminho.pt/mest/pgg/index_pgg.html, acesso em 5 abril 2013.

MANTESSO-NETO, V.; ANDRADE, W.T.F.; FRIGERIO, A.; STERN, A.G. 2012. Guia geoturístico e histórico de Santos e São Vicente. Santos: Sociedade Brasileira de Geologia, 46 Congresso Brasileiro de Geologia. 8p.

MARTINI, G.; ALCALÁ, L.; BRILHA, J.; IANTRIA, L.; SÁ, A.; TOURTELLOT, J. 2012. Reflections about the geotourism concept. In: Sá, A.A., Rocha, D., Paz, A. \& Correia, V. (eds.) Proceedings of the 11th European Geoparks Conference. AGA - Associação Geoparque Arouca, Arouca, 5-6, pp. 187-188.

MAWE, J. 1812. Travels in the Interior of Brazil, particularly in the gold and diamond districts of that country. London: Longman. Disponível em purl.pt/17038/2/, acesso em 12 fevereiro 2013.
OSMAN, S.A.; RIBEIRO, O.C.F. 2007. Arte, história, turismo e lazer nos cemitérios da cidade de São Paulo. Licere, Belo Horizonte, v. 10, n.1, p. 1-15, abr. D i s p o n íve I e m : www.anima.eefd.ufrj.br/licere/pdf/licereV10N01_a 6.pdf, acesso em 21 março 2013.

PÉREZ-AGUILAR, A.; BARROS, E.J.; ANDRADE, M.R.M.; OLIVEIRA, E.S.; JULIANI, C.; OLIVEIRA, M.A.S. 2012. Geoparque Ciclo do Ouro, Guarulhos, SP. In: Schobbenhaus C., da Silva C.R. (eds) Geoparques do Brasil-Propostas. CPRM, Brasília, p. 543-582. D i s p o n í v l e m : www.cprm.gov.br/publique/media/GEOPARQUESdo BRASIL_propostas.pdf, acesso em 5 abril 2013.

PÉREZ-AGUILAR, A.; JULIANI, C.; BARROS, E.J.; ANDRADE, M.R.M.; OLIVEIRA, E.S.; BRAGA, D.A.; SANTOS, R.O. 2013. Archaeological Gold Mining Structures from Colonial Period Present in Guarulhos and Mairiporã, São Paulo State, Brazil. Geoheritage, February DOI 10.1007/s12371-013-0074-8. Disponível em link.springer.com/article/10.1007/s12371-0130074-8, acesso em 5 abril 2013.

PERINOTTO, J.A.J. 2009. História Geológica de Rio Claro (SP) e Região. 2009. In Antonio Carlos Sarti; Lluís Mundet i Cerdan. (Orgs.). Turismo e Arqueologia: Múltiplos Olhares. 1ed. Piracicaba (SP): Equilíbrio Editora, v. 1, p. 187-213.

PERINOTTO, J.A.J.; MANTESSO-NETO, V. 2013a. Geologia e geoturismo urbano: história ilustrada do centro de Rio Claro, SP. Resumo. Ouro Preto: Anais do II Simpósio Brasileiro de Patrimônio Geológico. CD.

PERINOTTO, J.A.J; MANTESSO-NETO, V. 2013b.Geologia e geoturismo urbano: história ilustrada do centro de Rio Claro, SP. Belo Horizonte: Geonomos, no prelo.

PREFEITURA MUNICIPAL DE SÃO PAULO. 2011. Cavas de ouro históricas do Jaraguá. Grupo de Trabalho PMSP, Relatório Final, Setembro (Portaria $\mathrm{n}$ ㅇ 115/2010/SVMA-PA. 2010-0.348.880-0).

RIBEIRO, R.R.; CHRISTOFOLETTI, S.R.; BATEZELLI, A.; FITTIPALDI, F.C.; ZANCHETTA, D. 2012. Inventário do Patrimônio Natural Geológico da Região de Rio Claro (SP). In: SBG, CONGRESSO BRASILEIRO DE GEOLOGIA, Santos, Anais, 46, publicação em CD-ROM.

RODRIGUES, N.M. 2012. Ensaios não destrutivos em monumentos pétreos paulistanos. Monografia de Trabalho de Formatura. Instituto de Geociências USP. $47 \mathrm{p}$.

SALLUN FILHO, W.; FAIRCHILD, T.R. 2005. Estromatólitos no Brasil - Um passeio pelo passado no shopping. Revista Ciência Hoje, vol. 37, n. 222, p. 22-29.

SANTOS, A.R. 2004. A grande barreira da Serra do Mar: da Trilha dos Tupiniquins à Rodovia dos Imigrantes. $\mathrm{O}$ Nome da Rosa, São Paulo, 128p.

SÃO PAULO. 1978. Decreto Estadual no 11.138, de 3 fevereiro de 1978. Dispõe sobre a organização da Secretaria de Estado dos Negócios da Agricultura e dá providências correlatas. São Paulo, Diário Oficial do 
Estado de São Paulo de 15/02/1978, Seção 1, p. 36.

D i s p o n í v e I

e $\mathrm{m}$

www.al.sp.gov.br/repositorio/legislacao/decreto/19

78/decreto\%20n.11.138,\%20de\%2003.02.1978.htm I, acesso em 5 abril 2013.

SÃO PAULO. 1958. Decreto Estadual n 32.283, de 19 de maio de 1958. Cria o Parque Estadual do Alto Ribeira. São Paulo, Diário Oficial do Estado de São Paulo de $20 / 05 / 1958$, p.2. Disponível e m http://www.al.sp.gov.br/norma/?id=114779, acesso em 5 abril 2013.

SÃO PAULO. 1979. Decreto Estadual no 13.426/79, de 16 de março de 1979. Cria a Secretaria de Estado da Cultura e dá providências correlatas. São Paulo, Diário Oficial do Estado de São Paulo de 16/03/1979. D i s p o n íve I e m www.al.sp.gov.br/repositorio/legislacao/decreto/19 79/decreto\%20n.13.426,\%20de\%2016.03.1979.htm , acesso em 5 abril 2013.

SÃO PAULO. 1986. Decreto Estadual no 24.931, de 20 de março de 1986. Reorganiza o Instituto Geológico, da Coordenadoria da Pesquisa de Recursos Naturais, da Secretaria de Agricultura e Abastecimento, e dá providências correlatas. São Paulo, Diário Oficial do Estado de São Paulo de 20/03/1986. Disponível em www.al.sp.gov.br/repositorio/legislacao/decreto/19 86/decreto\%20n.24.931,\%20de\%2020.03.1986.htm , acesso em 5 abril 2013.

SÃO PAULO. 1987. Decreto Estadual no 26.942, de 01 de abril de 1987. Dispõe sobre a transferência e a vinculação de órgãos e entidades à Secretaria do Meio Ambiente. São Paulo, Diário Oficial do Estado de São Paulo de 01/04/1987. Disponível em www.al.sp.gov.br/repositorio/legislacao/decreto/19 87/decreto\%20n.26.942,\%20de\%2001.04.1987.htm , acesso em 5 abril 2013.

SÃO PAULO. 1989. Constituição Estadual, de 05 de outubro de 1989. Constituição Paulista. São Paulo, Diário Oficial do Estado de São Paulo de 05/10/1989. D i s p o n í v e I e $\mathrm{m}$ www.al.sp.gov.br/repositorio/legislacao/constituica o/1989/constituicao\%20de\%2005.10.1989.htm, acesso em 5 abril 2013.

SÃO PAULO. 2009. Resolução no 76, de 05 de novembro de 2009. Dispõe sobre a criação do Conselho Estadual de Monumentos Geológicos. São Paulo, Secretaria de Estado do Meio Ambiente, Diário Oficial de São Paulo de 05/11/2009, Seção 1, p. 42. Disponível em w w w. a m bi e n t e. s p.gov. br/w p content/uploads/resolucao/2009/2009_res_est_sm a_76.pdf, acesso em 5 abril 2013. SCHOBBENHAUS, C.; SILVA, C.R. da. (Orgs.). 2012. Geoparques do Brasil: propostas. Vol. I. Rio de Janeiro: CPRM - Serviço Geológico do Brasil. Disponível em www.cprm.gov.br/publique/media/GEOPARQUESdo BRASIL_propostas.pdf, acesso em 5 abril 2013.
SEADE - Fundação Sistema Estadual de Análise de Dados. 2013. Perfil do Estado de São Paulo: Território e População: Ano 2010. Disponível em http://www.seade.gov.br/produtos/perfil_estado/in dex.php, acesso em 28 agosto 2013.

SILVA, F.A.N. 2013. Comunicação pessoal.

SILVA, J.B.A.; ANDRADA, M.F.R. Viagem mineralogica na Provincia de São Paulo. 1963. In: Edgar Cerqueira de Falcão (Org.). Obras científicas, políticas e sociais de José Bonifácio de Andrada e Silva. Edição monumental comemorativa do bicentenário de seu nascimento. Brasília: Câmara dos Deputados, Vol. I, pg. 503-536.

STERN, A.G.; RICCOMINI, C.; FAMBRINI, G.L.; CHAMANI, M.A.C. 2006. Roteiro geológico pelos edifícios e monumentos históricos do centro da cidade de São Paulo. Revista Brasileira de Geociências. São Paulo, v. 36, n. 4, p. 704 - 711. Disponível em rbg.sbgeo.org.br/index.php/rbg/article/view/1253/ 945; acesso em 28 março 2013.

ZAINE, M.F.; PERINOTTO, J.A.J. 1996. Patrimônio natural e história geológica da região de Rio Claro/SP. Arquivo Público e Histórico do Município de Rio Claro, Rio Claro, 91p.

ZAINE, M.F.; ZAINE, J.E. 2009. Patrimônios naturais de Rio Claro (SP) e Região. In: Antonio Carlos Sarti; Lluís Mundet i Cerdan. (Org.). Turismo e Arqueologia: Múltiplos Olhares. 1a ed. Piracicaba (SP): Equilíbrio Editora, v. 1, p. 215-260.
Manuscrito ID 32741

Submetido em julho de 2013 Aceito em setembro de 2013 